\title{
The 2008 Financial Crisis and Taxation Policy
}

\author{
Thomas Hemmelgarn \\ Gaetan Nicodeme
}

CESIFo WORKING PAPER NO. 2932

CAtegory 1: Public FinANCE

JANUARY 2010
An electronic version of the paper may be downloaded
- from the SSRN website:
www.SSRN.com
- from the RePEc website:
- from the CESifo website:
www.CESifo-group.org/wp




\title{
The 2008 Financial Crisis and Taxation Policy
}

\begin{abstract}
The 2008 financial crisis is the worst economic crisis since the Great Depression of 1929. It has been characterised by a housing bubble in a context of rapid credit expansion, high risktaking and exacerbated financial leverage, leading to deleveraging and credit crunch when the bubble burst. This paper discusses the interactions between tax policy and the financial crisis. In particular, it reviews the existing evidence on the links between taxes and many characteristics of the crisis. Finally, it examines some possible future tax options to prevent such crises.
\end{abstract}

JEL-Code: E62, F21, F30, G10, H20, H30, H50, H60.

Keywords: financial crisis, tax policy, taxation, fiscal stimulus, financial transaction tax, property tax.

\author{
Thomas Hemmelgarn \\ European Commission \\ thomas.hemmelgarn@ec.europa.eu
}

\author{
Gaetan Nicodeme \\ European Commission \\ gaetan.nicodeme@ec.europa.eu
}

This version: 11th January 2010

The findings, interpretations, and conclusions expressed in this paper are entirely those of the authors and should not be attributed to the European Commission. The authors thank JeanPierre De Laet, Geoff Lloyd and Florian Wöhlbier for useful comments. They also thank Marco Fantini and Florian Wöhlbier for data on property taxation revenue. Possible errors and omissions are those of the authors.

(C) European Communities, 2010 


\section{Introduction}

The 2008 financial crisis has severely hit the world economy. While taxes have not generated the crisis, some aspects of tax policy may have led to increased risk-taking and indebtedness of banks, households and companies. Tax incentives may indeed have exacerbated the behaviour of economic agents, leading them to wrong economic decisions. There is evidence that tax systems around the world usually favour homeownership for instance. This situation may in turn lead to too-high demand in the housing market, boosting prices, which, combined with lax lending practices, paves the way for a speculative bubble. On another note, the favourable treatment of debt-financing relative to other sources may lead to leverage practices that are not anymore driven by pure economic conditions. This in turn may put at risk companies during economic downturns.

This paper proposes a detailed account of the conditions that have led to the banking crisis and the type of policy responses brought by the U.S. and the Member States of the European Union (EU). Monetary and regulatory policies have opened the possibility for a housing bubble which eventually burst and created a credit crunch because of a lack of confidence between actors on financial markets. Governments and Central banks reacted by a combination of capital and liquidity injections, regulatory measures and fiscal stimulus. A reading of the events and of existing economic literature makes us doubt that tax policy has been a major contributor to the housing bubble. There is however some theoretical suggestions that tax policy may have led to high levels of risk-taking because of the tax treatment of some executive compensation schemes and tax arbitrage possibilities on financial markets. Finally, we also find mixed arguments on the potential effects of a financial transaction tax to prevent future bubbles. Ending the preferential tax treatment of debt seems a more promising avenue to avoid risky leverage of firms.

The paper is organised as follow. Section (2) provides an introduction to developments of the 2008 financial crisis and introduces the latest available (current and forecast) economic figures. Section (3) takes stock of the policy measures taken by authorities, in particular the recovery plans and the tax measures taken to fight the crisis. Section (4) offers a reflection on whether specific tax provisions may have aggravated the crisis by encouraging home-ownership and risky behaviours. In particular, it looks at developments in the housing markets, the compensation of executives, and the development of securitization. These three elements have played a major role in the 
context of the crisis. Finally, the last section discusses some possible tax solutions to prevent future crises such as a transaction tax and tax systems that would be more neutral vis-à-vis the sources of financing.

\section{The build-up to the $\mathbf{2 0 0 8}$ financial crisis.}

\subsection{General economic conditions before the crisis.}

The events leading to the current financial and economic crisis are heavily debated and the dust has not yet settled on the real causes of the crisis. The arguments set in this paper are therefore somewhat speculative, subject to debates and will eventually be judged by History. Yet, a majority of commentators point to several elements that have facilitated an easing of credit and an increase in risk-taking.

The economic conditions in the early 2000s were characterised by the end of the dot-com bubble which peaked in March 2000 before bursting until the end of 2002 (figure 1). The reaction of the Federal Reserve to this stock market decline has been to ease economic conditions using declining interest rates. Accordingly, the U.S. Primary Credit Discount Rate was progressively lowered from $6.5 \%$ at the peak of the bubble in mid-2000 to $1 \%$ by mid-2003 (figure 2 ) $^{2}$.

Figure (1): Nasdaq Composite Index 1993-2004

Nasdaq Composite Index

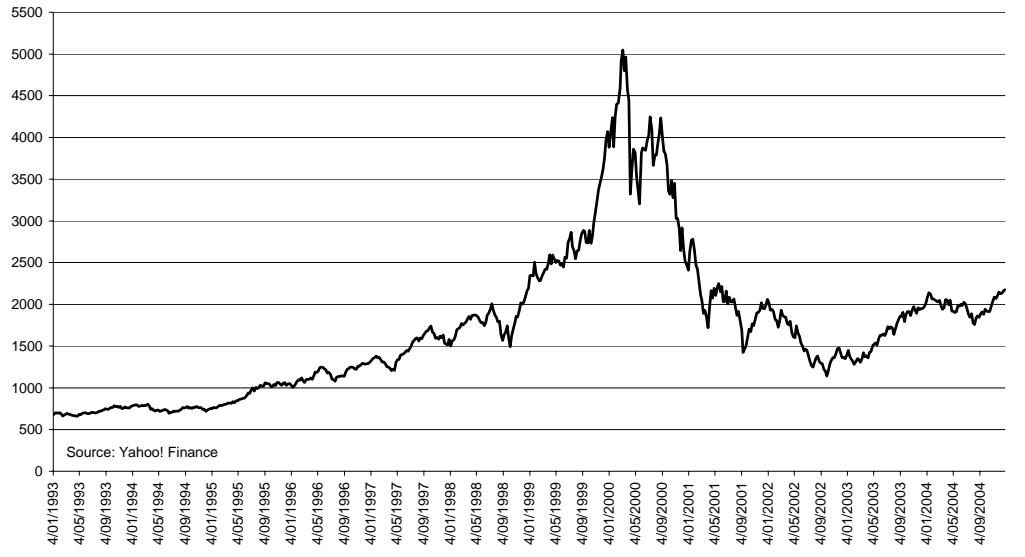

2 Note that the Federal Reserve most certainly also tried to combat the economic consequences of the September 11th, 2001 terrorist attacks. The U.S. economy was also in a context of low inflation, if not of deflation risk, which facilitated an ease in monetary policy. 


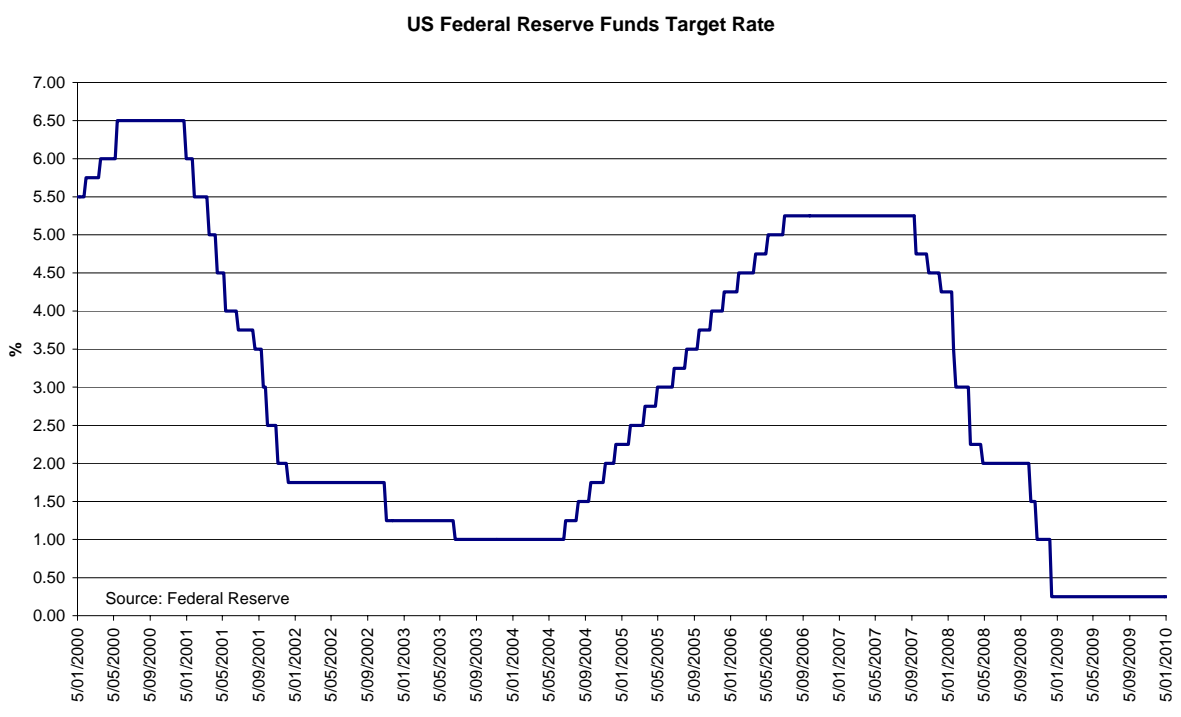

A second characteristic of the world economy in the early 2000s was massive inflows of capital on international financial markets. The U.S. Capital and Financial Account is illustrative of this phenomenon (see figure 3) ) $^{3}$ Between 1995 and 2000, it increased from $1.54 \%$ to $4.25 \%$ of GDP and continued to rise in the first half of the 2000 's to peak at $6.10 \%$ of GDP in 2006. The main driver of this expansion was net portfolio investment, which grew from USD 42.7 billion in 1998 to over USD 807 billion in 2007 - a twenty-fold increase over nine years (figure 4). Therefore, the U.S. economic situation in the first half of the 2000s was characterised by rapid economic recovery with low interest rates, increasing financial inflows and a high degree of risk-aversion in stock markets, following the tech bubble burst. ${ }^{4}$

3 The Capital and Financial account is composed of the net capital transfers, the change in the domestically-owned assets abroad, and the change in foreign-owned assets at home. It mirrors the current account (which is composed of the trade balance and the net unilateral current transfers). 
US Capital and Financial Account

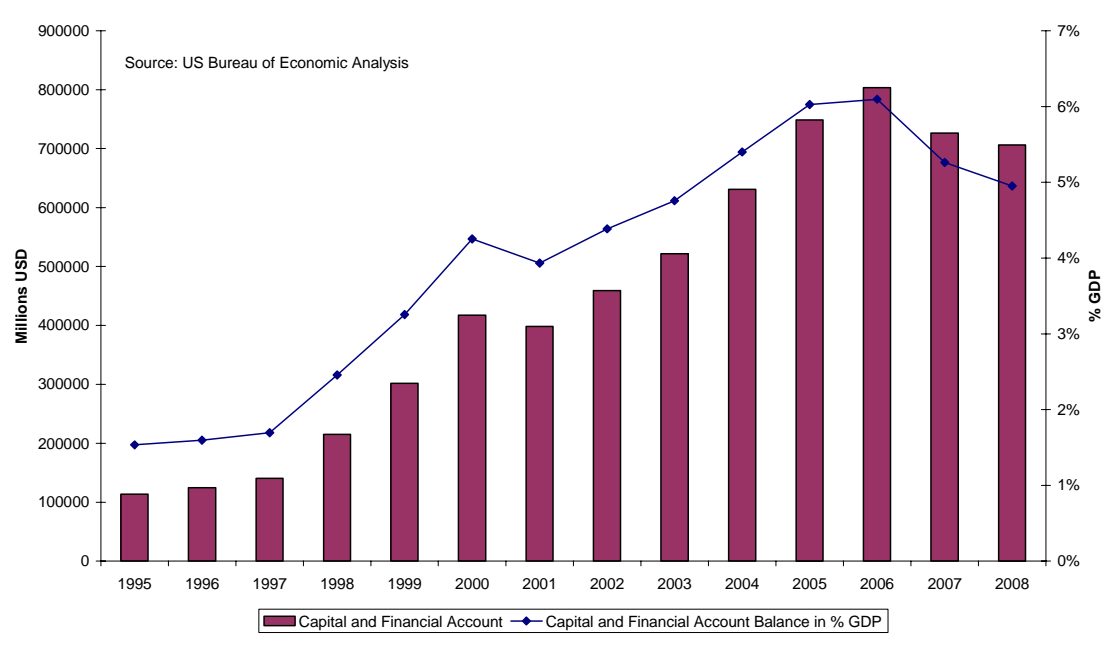

Figure (4): U.S. Capital and Financial Account: components

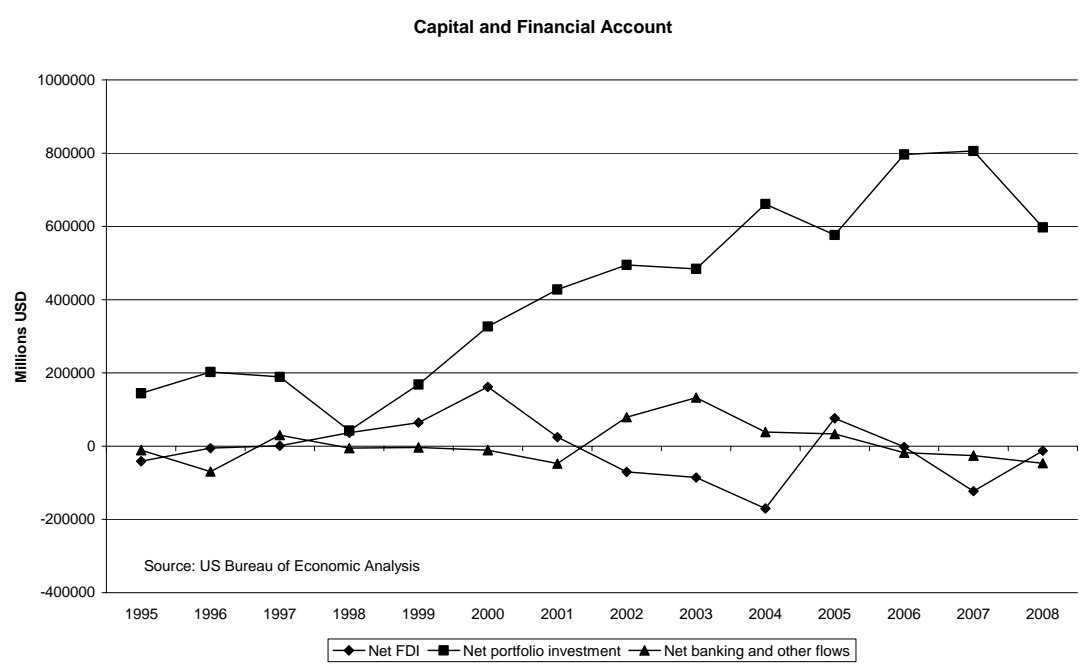

\subsection{Promotion of home ownership, deregulation and subprime credits.}

In their search for new places where to invest, many economic agents saw property as safer and more profitable. The conditions were consequently slowly put in place for a housing bubble. In four years - between 2001 and 2005 - the number of houses sold increased by $41.3 \%$ and the average price rose by $39.3 \%$. In addition to economic conditions (low interest rates, large inflow of capital that needed to be recycled

${ }^{4}$ This development is part of major global imbalances which also contributed to the crisis. See Portes (2009) for a more detailed description on the role of global imbalances. 
in the economy and cold feet of investors towards stock markets), several regulatory measures have also created incentives towards home-ownership.

Figure (5): Home sales and prices in the US

US housing market

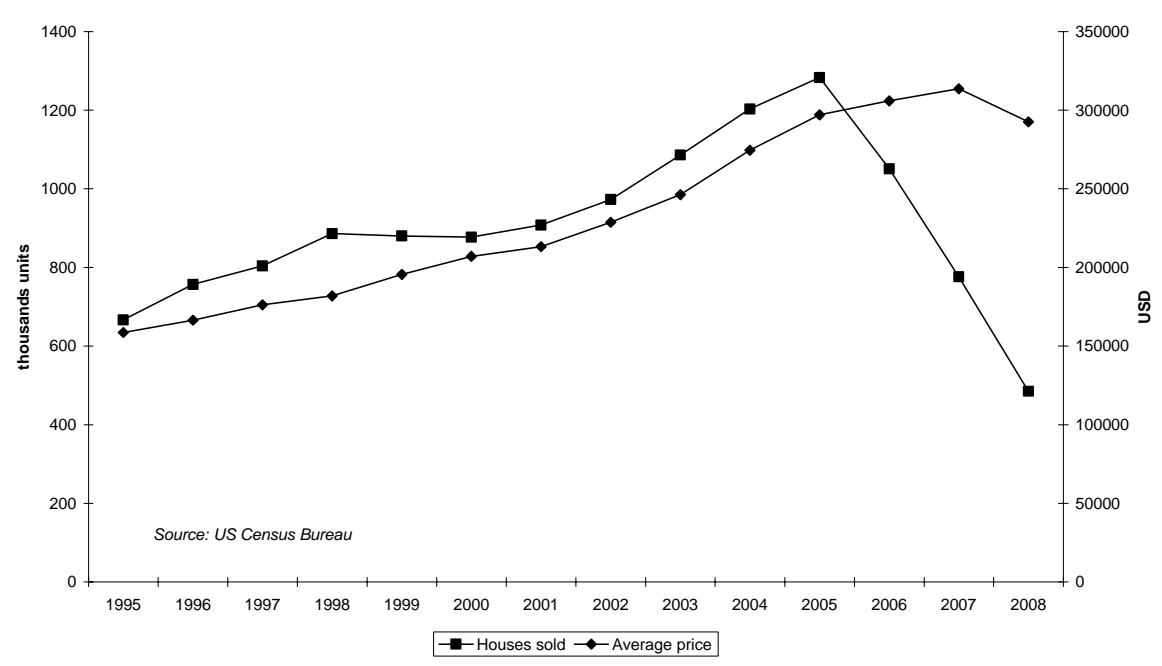

First, politicians desired to expand home-ownership, especially for poorer families. In the U.S., two institutions played a particular role in this policy: Fannie Mae and Freddie Mac. The former (officially named the Federal National Mortgage Association) was created in 1938 under the Roosevelt administration to buy and securitize mortgages to ensure enough liquidity for lending institutions. It became a subsidised - albeit independent - body in 1968 and was complemented in 1970 by a competitor, Freddie Mac (Officially named the Federal Home Loan Mortgage Corporation), which achieved similar functions on this secondary mortgage market. The role of Fannie Mae and Freddie Mac is to purchase loans from mortgage sellers such as banks and financial institutions, securitize them into mortgage-backed bonds and resell those on the secondary market, guaranteeing the principal and interest of the loan in exchange of a fee. It proves therefore to be a powerful instrument to refuel lending institutions with fresh cash and subsequently allow them to engage in additional lending activities. Fannie Mae and Freddie Mac have also been instrumented at varying degrees 
by U.S. administrations to expand housing credit to middle- and low-income families as well as in distressed areas ${ }^{5}$.

Second, the U.S. tax system contained several incentives for home-owners to take mortgages. For example, the 1986 Tax Reform Act disallowed consumers to deduct interest payments from consumers' loans (car loans, credit cards loans, etc.). This creates a perverse incentive for home-owners to use or refinance their home mortgages - whose interest payments remain deductible - to pay off their other debts or to extract cash for personal expenses. This incentive has been increasingly larger because of the wealth effect of ever-rising home values. In addition, the 1997 Taxpayer Relief Act quadrupled the tax exemption for capital gains - giving further incentives to buy houses - and the 2002 Single-Family Affordable Housing Tax Credit Act and the 2004 American Dream Downpayment Act provides further fiscal measures in favour of home ownership.

Financial institutions reacted to this by opening the credit tap, helped by more lax regulations. The 1999 Gramm-Leach-Bliley Act repealed some of the provision of the 1933 Glass-Steagall Act that disallowed financial institutions to combined commercial, insurance and investment activities and this might have led to more risk-prone attitudes from the part of commercial banks ${ }^{6}$. Risk-taking was also encouraged by relaxed rules on capital adequacy and new accounting standards. The decision on $28^{\text {th }}$ April 2004 by the Securities and Exchange Commission to loosen the capital rules for large financial institutions (following their request) and to let computer models of those investment companies determine the level of risk of investment (i.e. de facto self-monitoring) led to a sharp increase in the leverage of the main U.S. financial institutions ${ }^{7}$. This trend was also facilitated by the BASEL-II agreements, which entered into force in 2008 and gave more scope for financial institutions to assess their risks, as well as by the introduction of

\footnotetext{
5 See the 1977 Community Reinvestment Act (CRA), which was extended by the 1992 Federal Housing Enterprises Financial Safety and Soundness Act and scrutinized by the 1995 New Community Reinvestment Act, or the decision of the Department of Housing and Urban Development in 2000 to order Fannie Mae to devote half of its business to poorer families, which was increased to a 56\% goal in 2004. 6 See Lloyd (2009).

See http://securities.stanford.edu/news-archive/2004/20040428_Headline08_Drawbaugh.htm; http://www.nytimes.com/2008/10/03/business/03sec.html . Between 2003 and 2007, the leverage of the top 5 U.S. financial institutions evolved as follow: Lehman Bothers from 22.7\% to 29.7\%, Bear Stearns from $27.4 \%$ to $32.5 \%$, Merrill Lynch from $15.6 \%$ to $30.9 \%$, Goldman Sachs from $17.7 \%$ to $25.2 \%$ and Morgan Stanley from $23.2 \%$ to $32.4 \%$. In 2007, their total debt amounted to USD 4.1 trillion, a third of U.S. GDP (sources: Wikipedia using annual reports http://www.lehman.com/annual/2007/fin highlights/; http://www.bearstearns.com/sitewide/investor_relations/sec filings/proxy/index.htm;

http://ir.ml.com/sec.cfm?DocType=Annual\&Year=2008; $\quad \underline{\text { http://www2.goldmansachs.com/our- }}$ firm/investors/financials/current/annual-reports/revised-financial-section-2007.pdf; http://www.morganstanley.com/about/ir/shareholder/10k2007/10k11302007.pdf )
} 
the International Accounting Standards in 2005, which forced companies to register immediately gains and losses on financial assets, leading to more stock volatility.

In this context, the proportion of subprime mortgages ${ }^{8}$ soared from $7.2 \%$ of the total in 2001 to over $20 \%$ in 2005 and 2006 (figure 6). Gambling was also at play as some studies pointed out that over a third of the houses bought were for investment or second residence purposes and those specific acquisitions were made with the hope that continued price increases would allow buyers to resell with profit. Accordingly, a third of the loans made in 2002 were either interest-only (where only interest is repaid) or negative amortization loans (where less than the interest is paid during a first period and the accrued unpaid interest is added to the outstanding amount of the loan) ${ }^{9}$. Moreover, an increasing number of loans were granted with adjustable-rates (ARM) ${ }^{10}$ between 2001 and 2004 - mostly for the two pre-cited types of loans - and this despite stabilising interest rates, which possibly indicates an increasing number of credit-constrained borrowers (figure 7).

8 By definition, a subprime loan is a loan that does not meet the 'prime' standards and is consequently risky. There may be various elements that make the loan fail the 'prime test' (e.g. length, structure, etc.). In this context, it is the profile of the borrower and/or the difference between the loan and the value of the house or the collateral. Loans are usually classified based on the Government-sponsored enterprises' guidelines. When a credit fulfils the GSE's criteria, it is labelled conventional. When the loan fulfils all guidelines but the amount of the credit (usually loans above USD 300,000), it is labelled as Jumbo. In those two cases, the creditworthiness of the borrower is not questioned and both loans are 'Prime' Loans. Non-Prime Loans can be Alternative-A when for instance the borrower has income that is difficult to assess (e.g. self-employed), a high debt-to-income ratio, few documentation, or several mortgaged houses. In this case the creditworthiness if not questioned but there is a higher risk. They can also be Home-Equity Loans, which is a heterogeneous category of second- and first-lien mortgages with high loan-to-value ratios, home improvement loans and revolving home-equity lines of credits. Finally, it also includes the subprime loans with low-credit-quality borrowers (Fabozzi, 2005)

${ }^{9}$ The Economist, $16^{\text {th }}$ June 2005.

10 For subprime mortgages, the proportion of fixed rate mortgages dropped from $33.2 \%$ in 2001 to $18.6 \%$ in 2005, while the bulk of the loans were of hybrid nature (i.e. with a fixed rate during an initial period of 2-3 years and then adjustable based on a reference rate) and not pure ARM. From 2005, the share of balloon mortgages in subprime mortgages jumped to reach $25 \%-30 \%$. Those mortgages require a large 
Figure (6): Prime and subprime U.S. mortgages

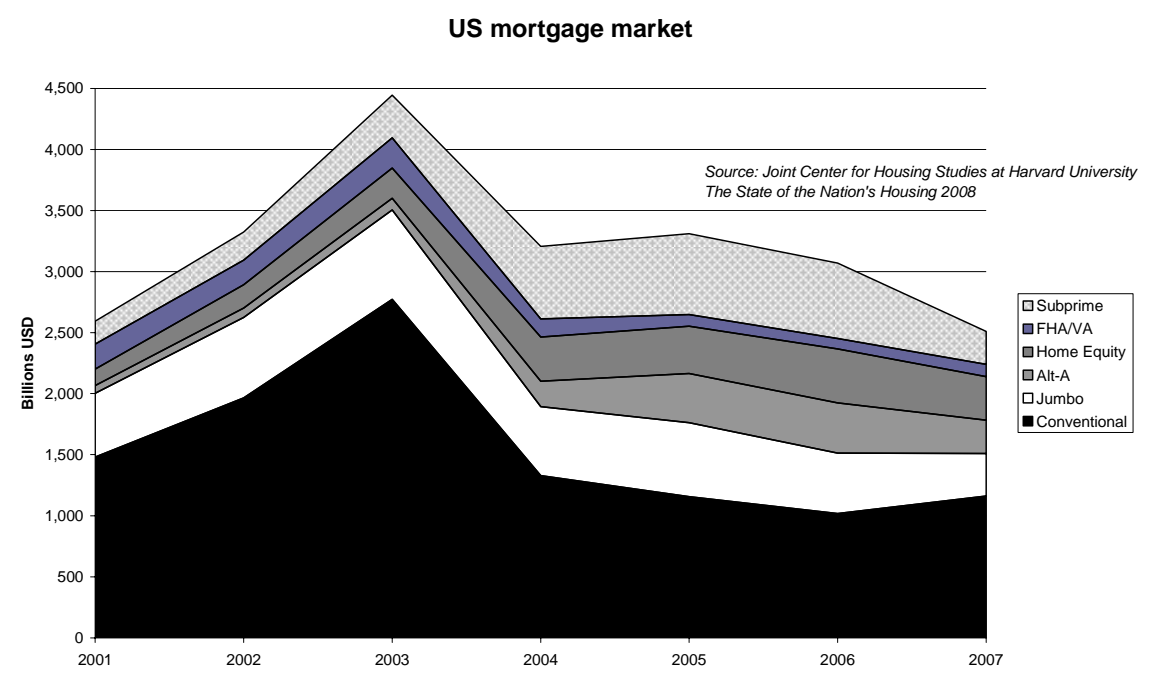

Figure (7): Adjustable-Rate Mortgages

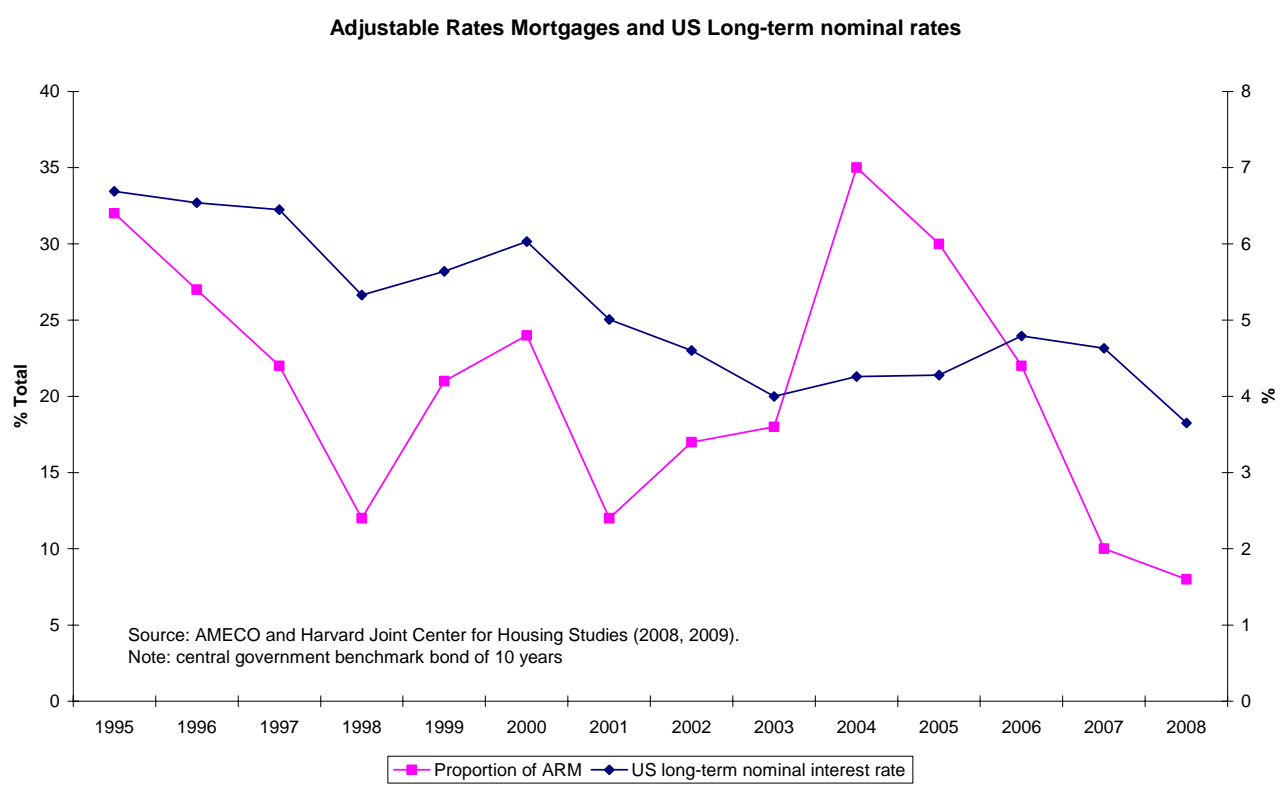

\subsection{The securitization of mortgages}

The spread of mortgages, in particular subprime loans, was largely helped by the development of new financial instruments, in particular the technique of securitization, which consists of pooling the loans into an investment vehicule and then selling securities backed by payments for these loans. In the case of mortgages, those financial instruments are Mortgage-Based Securities (MBS). Typically, the financial institution 
will buy the claims of thousands of mortgages and pool them into a so-called special purpose vehicule (SPV), which is a legal entity outside of the balance-sheet of the financial institution, allowing them to bypass capital ratios regulations. The securities are separated in several tranches - senior, mezzanine (or junior) and equity (non-investment grade) - with a sequential preference for the claims (i.e. the senior tranche has preferred claim on the proceeds over the other two and the mezzanine tranche has preference over the equity tranche). By doing so, financial institutions are able to rearrange the risk of the pool and to redistribute it across investors with different risk-aversion ${ }^{11}$. This in turn lowers the cost of lending and extents credit to borrowers with lower credit quality.

An important development has been the issue of Collaterized Debt Obligations (CDOs), a family of Asset-Based Securities which is backed by diversified debtobligations such as mortgages-backed securities, corporate bonds, bank loans, credit cards debt, etc ${ }^{12}$. While a MBS is backed by mortgage payments, a CDO is backed by Mortgage-Based Securities within a portfolio and represents therefore a re-securitisation (Baily et al, 2008). The advantage of a CDO is that it allows financial institutions to rearrange the securities into new compartments within the CDO and to transform lowrated MBS into high-rated CDOs. According to Baily et al. (2008), CDO issuances went from virtually zero in 1995 to over USD 500 billion in 2006 and virtually all CDOs issued over the last years were backed by low-rated subprime MBS.

This securitization process was itself helped by the emergence of a new class of derivatives which allowed transferring the credit risk to a third party: the Credit Default Swaps (CDS). CDS are common instruments, representing 73\% of the USD 2.3 trillion credit derivative products in 2002 (O'Kane, 2005). The principle is that a third party accepts to take the default risk of a specific asset in exchange of an income. This process allows the CDO issuer to shield from the risk and to increase the rating of its bonds. The CDS market has mainly developed outside organised markets (i.e. they were Over-TheCounter operations) and grew exponentially from virtually zero in 2001 to about USD 15 trillion in 2005 and over USD 60 trillion in 2007 (Baily et al., 2008).

\subsection{The bubble burst.}

$30 \%-40 \%$ of the loans were to buy a house (Demyanyk and Van Hemert, 2009).

11 See Fabozzi (2005) for a description of these instruments and Baily et al. (2008) for a brilliant description of the processes.

12 See Fabozzi (2005), chapters 30 and 31. 
With U.S. inflation rising from $1.6 \%$ in 2002 to $2.3 \%$ in $2003,2.7 \%$ in 2004 , $3.4 \%$ in 2005 , peaking at $4.3 \%$ in June $2006^{13}$, the Federal Reserve gradually raised interest rates from $1 \%$ to $5.25 \%$ (see Figure 2) and the first cracks appeared in the housing market. Some borrowers, especially those with adjustable-rate mortgages (ARM), started feeling the pain and could eventually not repay their mortgage. The number of foreclosures increased exponentially from 885,000 in 2005 to $1,259,118$ in 2006, 2,203,295 in 2007 and 3,157,806 in $2008^{14}$. The number of houses sold declined and prices levelled off before plunging (see figure 5).

Financial institutions started to be hit as they were heavily indebted and exposed via Mortgage-Backed Securities, whose value are based on mortgage payments and house values. HSBC announced in February 2007 that it was writing down for USD 10.5 billions of subprime MBS. This event was followed in April by the bankruptcy of New Century Financial, the U.S. largest subprime lender. In July, the collapse of two hedge funds run by Bear Stearns because of subprime losses was another alarming sign of deterioration as were the announcements of heavy losses in other financial institutions, putting some of them on the verge of bankruptcy (e.g. Bear Stearn) - with in some cases bank runs (e.g. Nothern Rock in the UK). The near-collapse of the banking system happened in September 2008. On $7^{\text {th }}$ September, ailing Government-sponsored enterprises Fannie Mae and Freddy Mac were urgently nationalised. On $14^{\text {th }}$ September, Merrill Lynch saw itself close to illiquidity and was sold to Bank of America. The next day, Lehman Brothers filed for bankruptcy, and the day after, American International Group (AIG), one of the largest CDS providers, avoided bankruptcy only thanks to a USD 85 billion loan from the Federal Reserve ${ }^{15}$. The uncertainty about external positions and liquidity or solvability of financial institutions led to a sharp drop in confidence among financial market actors. This led in turn to a sharp increase in the TED Spread an indicator of perceived credit risk - which went over 300 basis points on $17^{\text {th }}$ September ${ }^{16}$ and to a sharp fall in the interbank lending activities (see figure 8). These financial problems spread into the real economy via a credit crunch, creating a drop in available funds for private investment.

\footnotetext{
13 Inflationdata.com

14 Realtytrac.com

15 See Wibaut (2008) for an excellent description of the events.

16 The TED spread is the difference in basis points between the short-term interbank rate (i.e. the LIBOR) and the 3-month U.S. treasury rate. Its historical fluctuation is between 10 and 50 basis points. On $10^{\text {th }}$ October 2008, it reached a record 465 basis points (http://www.tedspread.com)
} 
U.S. Interbank loans

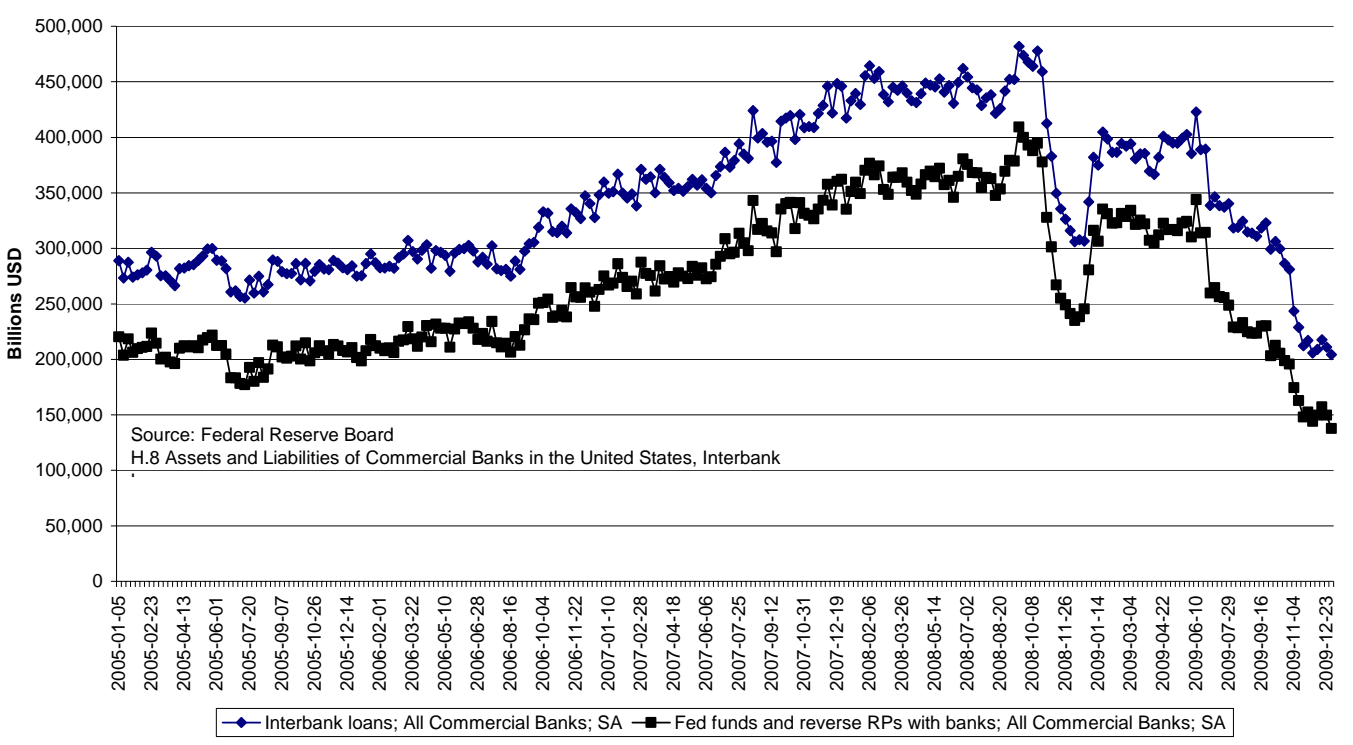

The banking crisis also quickly spread to stocks markets. The S\&P-500 index started to decline from its highest value of 1565.15 points on $9^{\text {th }}$ October 2007 to 1251.70 points on $12^{\text {th }}$ September 2008 , a decline of more than $20 \%$ in less than a year. On $15^{\text {th }}$ and $17^{\text {th }}$ September, amid large financial institutions' turmoil, it lost twice an additional 4.71\%. The descent into hell was not over yet with stock crashes of 8.8, 7.6, 9.0 and $8.9 \%$ on $29^{\text {th }}$ September, $9^{\text {th }}$ October, $15^{\text {th }}$ October and $1^{\text {st }}$ December, respectively. On $9^{\text {th }}$ March 2009, the S\&P-500 index stood at its lowest point so far: 676.53 points, only $43.2 \%$ of its value 15 months earlier.

\subsection{Comparison with previous crises and economic outlook.}

Figure (9) compares the 2008 crisis with some previous stocks crashes: the 1929 Great Depression, the 1973 Oil Shock, the 1987 Black Monday and the 2000 IT bubble ${ }^{17}$. It shows the historically extreme severity of the stock markets' decline. Interestingly, the 2008 financial crisis started on the same paths as the 1973 oil shock before dropping on

${ }^{17}$ Check also http://dshort.com/ for a wealth of charts and analysis on the 2008 crisis. 
the same paths as the 1929 Great Depression ${ }^{18}$. Two additional interesting points are worth mentioning. First, the comparison reveals that the stock decline can be long. The 1973, 2000 and 1929 stock declines last 626, 913 and 1,025 days respectively. At the time of writing, the 2008 crisis hit its bottom-low point after 517 days. Second, the return to pre-crisis levels takes very long. It took more than 7 years after the 2000 IT bubble and 7 1/2 years after the 1973 oil shock, while WWII never allowed stocks to return to their pre-1929 levels ${ }^{19}$. However - at the time of writing -, the 2008 crisis has one of the fastest recovery rate to date.

18 There are similarities but also large differences between the 1929 and the 2007 crises. Both crises originated in the U.S. and found their mechanisms in rapid credit expansion helped by financial innovation in a context of high leveraging, leading to funding problems, deleveraging and a credit crunch. However, the 1929 crisis started with a stock crash followed by a banking crisis while the reverse happened in 2008 . The differences are also reflected in the roots of the crises (tightening monetary policy and stock crash in 1929 versus a housing bubble in 2008) and initial conditions were also different (weak growth, fixed exchange rates, low inflation and no deposit insurance scheme in 1929 versus flexible exchange rates and high growth with inflationary pressures in 2008). Finally, policy answers also differ (decline in money supply, no stimulus and no coordination in 1929). See IMF (2009a) for a good review.

19 Actually, when taking inflation into account, we have not yet recovered from the IT bubble.

S\&P 500: 1950-2009

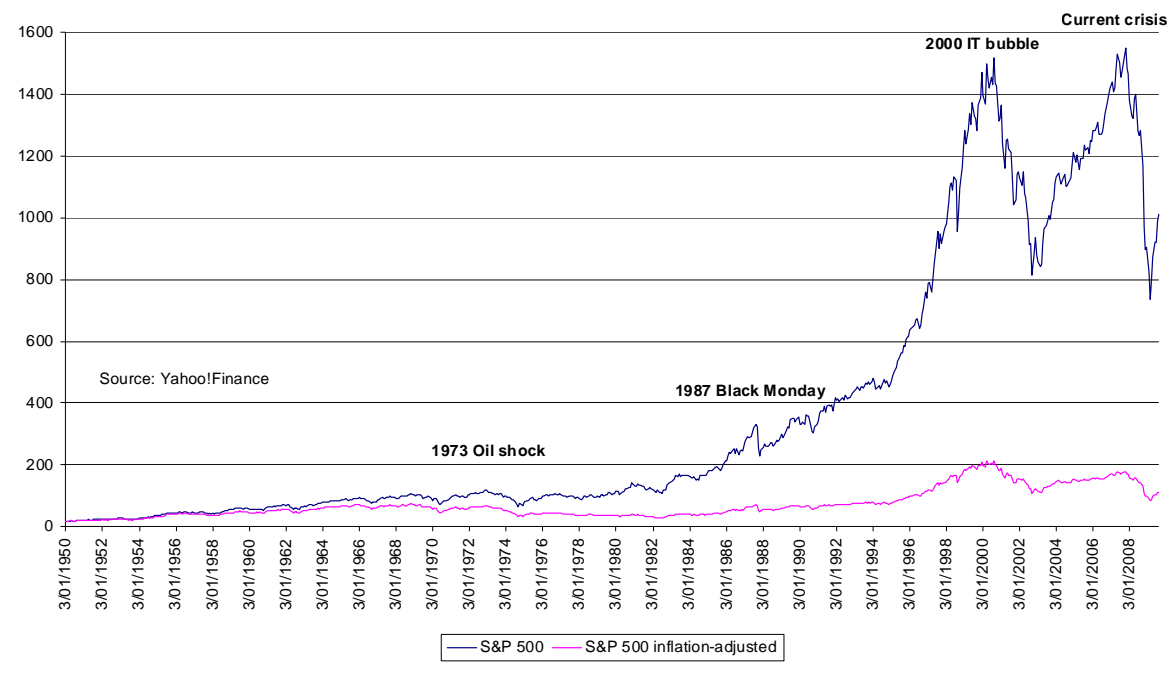


Financial crises compared (S\&P 500, Dow Jones for 1929)

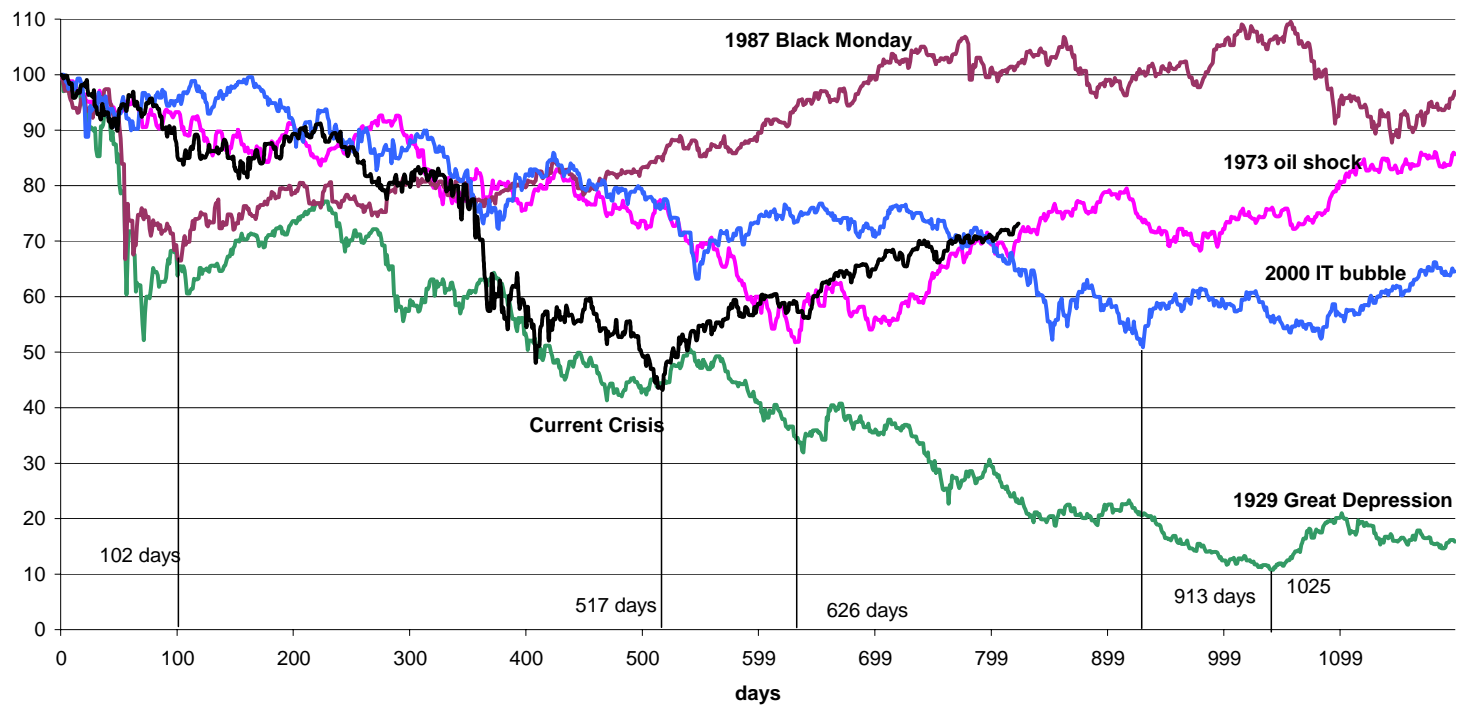

Previous crises also tell us about economic prospects. Leaven and Valencia (2008) and IMF (2009a) show that whereas GDP losses amount to $4 \%$ on average after a stock market crash, this loss is double after house-bubble bursts. In addition, economic recessions cost $2.7 \%$ of GDP and last 3.6 quarters on average whereas the same figures for financial crises and for highly synchronised recessions are 3.4\% and 5.7 quarters and $3.5 \%$ and 4.5 quarters respectively. The 2008 crisis may thus lead to a severe economic contraction. At the time of writing, the latest forecast were a severe contraction in $2009-$ with deflationary pressures - and close-to-zero growth in $2010^{20}$. There are however recent signs that major EU economies went out of recession during the second quarter of 2009, which could colour up these gloomy forecasts.

Two points may play an important role in the path to recovery. A first point is to restore the confidence of actors, in particular by cleaning up financial institutions from potentially toxic assets. Figure (10) shows that total exposure amounts to USD 52 trillion

20 The October 2009 IMF's estimate is a contraction of world's output by $1.1 \%$ in 2009 and a world recovery at $3.1 \%$ in 2010 . The figures for the U.S. are $-2.7 \%$ and $1.5 \%$ and those for the Euro-area are 4.2\% and 0.3\% (IMF, 2009a). The European Commission's latest forecast for the EU-27 is a fall by $4.1 \%$ in 2009 and a slow recovery of $0.7 \%$ in 2010 and 1.6\% in 2011 (European Commission, 2009d). 
(about $60 \%$ of which relates to EU banks) while the total write-downs needed is estimated to be USD 2.8 trillion (with EU banks representing about half). Table (1) indicates that a sizeable part of what is estimated to be needed still remains to be writtendown.

Figure (10): Write-downs estimated

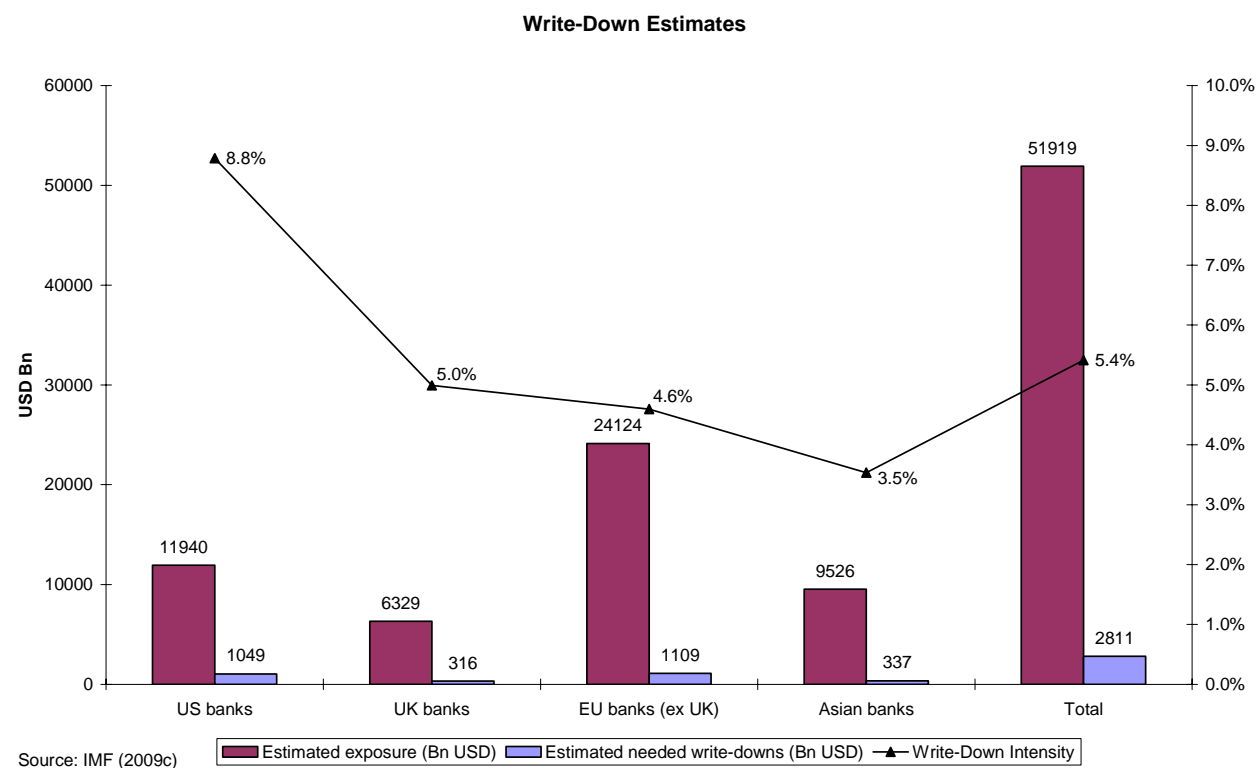

Table (1): write-down estimates

\begin{tabular}{|l|c|c|c|c|}
\hline Billions USD & US & Euro Area & UK & $\begin{array}{c}\text { Rest of } \\
\text { Western } \\
\text { Europe* }\end{array}$ \\
\hline Reported write-downs at end-2008 (1) & 510 & 154 & 110 & 70 \\
\hline Expected write-downs 2009-2010 (2) & 550 & 750 & 200 & 125 \\
\hline$(1) /((1)+(2))$ & $48.1 \%$ & $17.0 \%$ & $35.5 \%$ & $35.9 \%$ \\
\hline
\end{tabular}

*: DK, IC, NO, SE, CH. Source: IMF (2009c).

The second important point is fiscal sustainability. As we will see in section 3, the combination of economic recession and rescue and stimulus packages has put huge strains on public finance. For the EU, the average budget deficit is estimated to surge from $-0.8 \%$ in 2007 to $-7.5 \%$ by 2010 and public debt-to-GDP would jump from $58.7 \%$ in 2007 to $83.7 \%$ in 2011 (European Commission, 2009d). The path of the future exit strategy will need to take into accounts to links between taxation and growth.

\section{The policy response.}

One important and welcomed difference with the Great Depression is that public authorities have acted to provide a policy response to the crisis. Central banks have 
reacted in two ways to ease monetary conditions: injecting liquidity in the market and lowering interest rates. On $9^{\text {th }}-14^{\text {th }}$ August 2007, the Federal Reserve, The ECB and the Bank of Japan coordinated their efforts to respectively inject USD 64 Bio, EUR 229 Bio, and JPY 1 trillion $^{21}$ to provide banks with liquidities. New large injections of liquidities occurred ever since. Central Banks also rapidly lowered their interest rates, starting with a $1 \frac{2}{2} \%$ cut in the Federal Reserve discount rate on $17^{\text {th }}$ August 2007 . Other Central Banks followed suit and many additionally engaged in programmes to offer alternative funding.

In the midst of the crisis, governments were also forced to rescue banks to avoid a collapse of the whole financial system. For example, Member States of the European Union committed (individually) to recapitalisation of their financial institutions, guarantees on bank liabilities, relief of impaired assets and liquidity and bank funding support for a total representing $43.6 \%$ of their combined GDP (European Commission, 2009a, page 44). In the US, the Emergency Economic Stabilization Act enacted on $3^{\text {rd }}$ October 2008 consists in the Trouble Asset Relief Program (TARP, also known as the Paulson-Plan). This programme provides the U.S. Treasury with USD 700 billion to purchase 'trouble assets', mainly ailing Mortgage-Backed Assets and Collaterized Debt Obligations, and to buy preferred stocks of financial institutions. The hope of the U.S. government is that this new injection of capital would be used by those financial institutions to revive the credit market and, in the longer term, that the value of these assets would increase - possibly allowing the Treasury to recoup its investment.

The third part of the policy response to the crisis is the fiscal stimulus packages. A first step was the Economic Stimulus Act of $13^{\text {th }}$ February 2008 which provided U.S. taxpayers with various tax credits for a total of over USD 150 billion. On $26^{\text {th }}$ November 2008, the European Commission unveiled the European Economic Recovery Plan for Growths and Jobs (EERP), which includes a mix of tax and expenditure measures to support the real economy and to boost confidence. The plan proposes a EUR 200 billion (i.e. 1.5\% of EU GDP) fiscal stimulus, shared between the European Commission (EUR $30 \mathrm{Bio}$ ) and the Member States (EUR $170 \mathrm{Bio}$ ), and is made out of a set of proposed actions from which individual Member States can choose.

The various measures taken by the Member States in the context of the EERP have largely been documented (European Commission, 2009b, 2009c; Ernst \& Young,

\footnotetext{
${ }^{21}$ Fed: $\$ 24$ Bio on $9^{\text {th }}, \$ 38$ Bio on $10^{\text {th }}, \$ 2$ Bio on $13^{\text {th }}$; ECB: EUR 95 Bio on $9^{\text {th }}$, EUR 61 Bio on $10^{\text {th }}$, EUR 47.7 Bio on $13^{\text {th }}$ and EUR 25 on $14^{\text {th }}$. In comparison, the Fed injected $\$ 81.25$ Bio on $14^{\text {th }}$ September 2001 (Cecchetti, 2007).
} 
2009). The total fiscal impulse amounts to about $1.8 \%$ of EU GDP. It is however arduous to provide an exhaustive classification of the tax measures taken by EU Member States to fight the economic crisis, not the least because already decided measures may have been relabelled or modified to fit into national stimulus packages. Table (2) provides a tentative typology of tax measures that were taken in the EU. Generally, measures have consisted in a lowering of existing taxes but the budgetary position of some countries such as Latvia, Lithuania or Ireland (among others) - has forced those to increase taxes instead. The bulk of the measures have focused on a decrease in labour taxes, in particular by lowering personal income tax rates or increasing tax brackets. Another sizeable part of tax measures has focused on decreasing corporate income taxes, alternatively lowering the rate or the base. Interestingly, no country has acted to cut standard VAT to try to boost consumption, the UK being the (temporary) exception.

Table (2): Tax measures taken by EU-27 Member States

\begin{tabular}{|c|c|c|}
\hline & Lowering Taxes & Increasing Taxes \\
\hline \multicolumn{3}{|l|}{ Labour Taxes } \\
\hline Personal Income Tax & $\begin{array}{l}\text { OE, DK, FI, FR, DE, HU, LV, } \\
\text { LT, LU, MT, NL, PL, PT, SI, } \\
\text { SK, SE }\end{array}$ & EL, IE, UK \\
\hline SSC Employers & CZ, FI, HU, NL, SE & IE, RO, UK \\
\hline SSC Employees & CZ, NL, SE, SK & LT, RO, UK \\
\hline Withholding taxes & $\mathrm{BE}$ & \\
\hline Deductions & OE, BG, DE, IT, PT, SK, ES, SE & \\
\hline Capital Gains & RO & IE \\
\hline Deferral of reform & & $\mathrm{CZ}, \mathrm{EE}$ \\
\hline \multicolumn{3}{|l|}{ Corporate Income Tax } \\
\hline CIT rate & EL, LU, PT, SE & IT, LT \\
\hline Allowances & $\begin{array}{c}\text { OE, BG, ES, IT, NL, DE, FR, } \\
\text { LT, PL, PT, SI, SK }\end{array}$ & \\
\hline \multicolumn{3}{|l|}{ Value-Added Tax } \\
\hline Standard Rate & UK & HU, IE, LV, LT \\
\hline Reduced Rates & BE, CY, CZ, FI, FR, MT, RO & HU, EE, IE, LV, LT \\
\hline Property and inheritance taxes & EL, ES, IT, LU, PT & \\
\hline Environmental taxes & DE, NL, RO & FI, IT, LV, LT, SI, UK \\
\hline
\end{tabular}
Source: adapted from European Commission (2009c).

Finally, the American Recovery and Reinvestment Act, signed by President Obama on $17^{\text {th }}$ February 2009 provides a large stimulus package of about USD 800 bio. The plan contains tax cuts for individuals in the form of various tax credits for an estimated total of about USD 240 billion and tax cuts for companies for a total of about USD 50 billion, notably by extending the carry-forward of losses from two to five years.

\section{Have taxes aggravated the crisis?}

\subsection{The housing market}


The end of the speculative price bubble in the U.S. housing market has been identified as an important trigger for the financial crisis. As lined out above, U.S. Households received credits for consumption purposes on the assumption that the increase in house prices would be large enough to cover the outstanding credits. Figure (11) shows the Case-Shiller House Price Index for the U.S. and illustrates the strong increase in house prices since the end of last century and the dramatic decrease in house prices since $2006 .{ }^{22}$ With the end of increasing house prices, these credits and especially the accompanying securitized products (see also section 2.3 above) became toxic assets, leaving the financial sector with unknown risks in their balance sheets. This in turn led to a world-wide credit crunch as financial companies stopped lending money to each other since the risk that the trading partner would run out of liquidity had increased. At the end of the process, credits to other economic actors (e.g. households, companies) were also sharply reduced. This is one reason why the real economy started to suffer from the crisis at a later stage compared to the financial sector.

Figure (11): Case-Shiller House Price Index

\footnotetext{
${ }^{22}$ A description of the index can be found here:

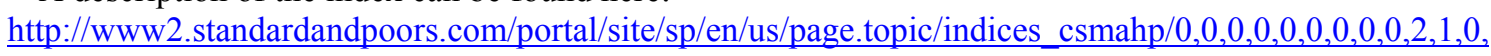
$\underline{0,0,0,0 . \mathrm{html}}$
} 


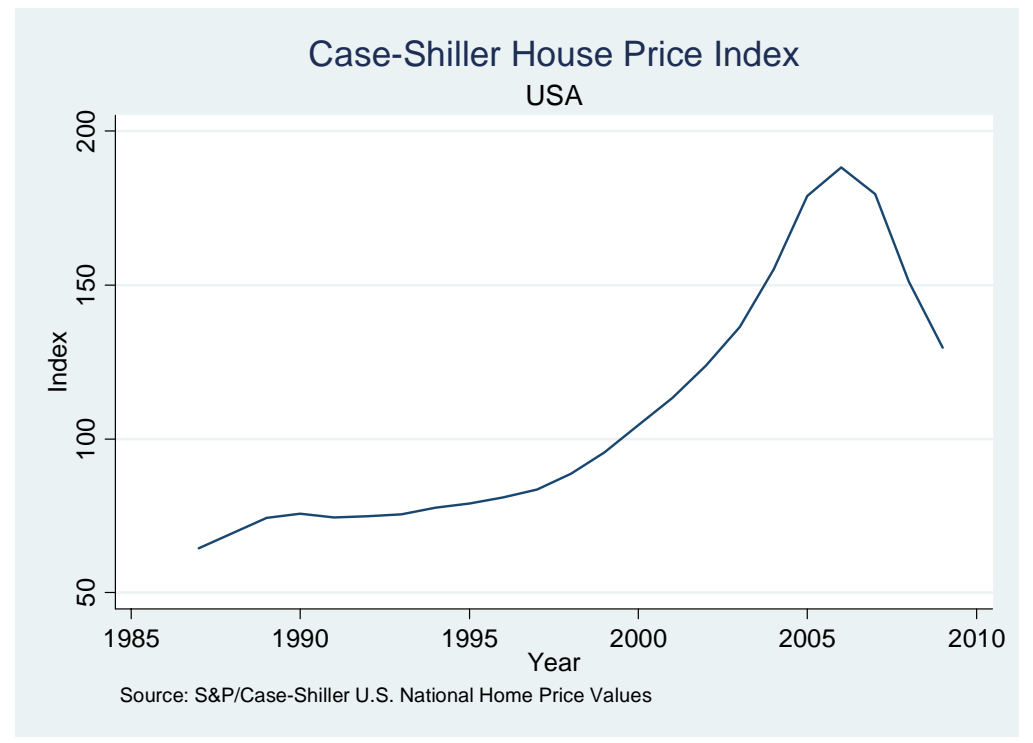

In Europe, Ireland and Spain faced similar price bubbles in the housing market and when the international crisis hit, this led to a severe downturn in those two countries which formerly showed some of the best economic performance in the Euro Area. Other European countries like the UK, France, Sweden and the Netherlands experienced similar increases in house prices over the last decades, albeit at a lower degree. ${ }^{23}$

While real house prices rose in many countries, the same was true for another important indicator of the attractiveness to own a house: the price-to-rent ratio. The ratio compares the discounted rents for a house with its current price. If the ratio is larger than 100 , it is more attractive to own a house, as renting is more expensive than buying a house. Comparing this ratio across countries allows comparing the incentives to own a house. As seen in figure (12), the price-to-rent ratio significantly increased in many countries over the last decade, especially Ireland and Spain. Ireland also faced the most dramatic decrease after the peak was reached in 2005.

Figure (12): Price to Rent Ratio

\footnotetext{
${ }^{23}$ See figure (13) below.
} 


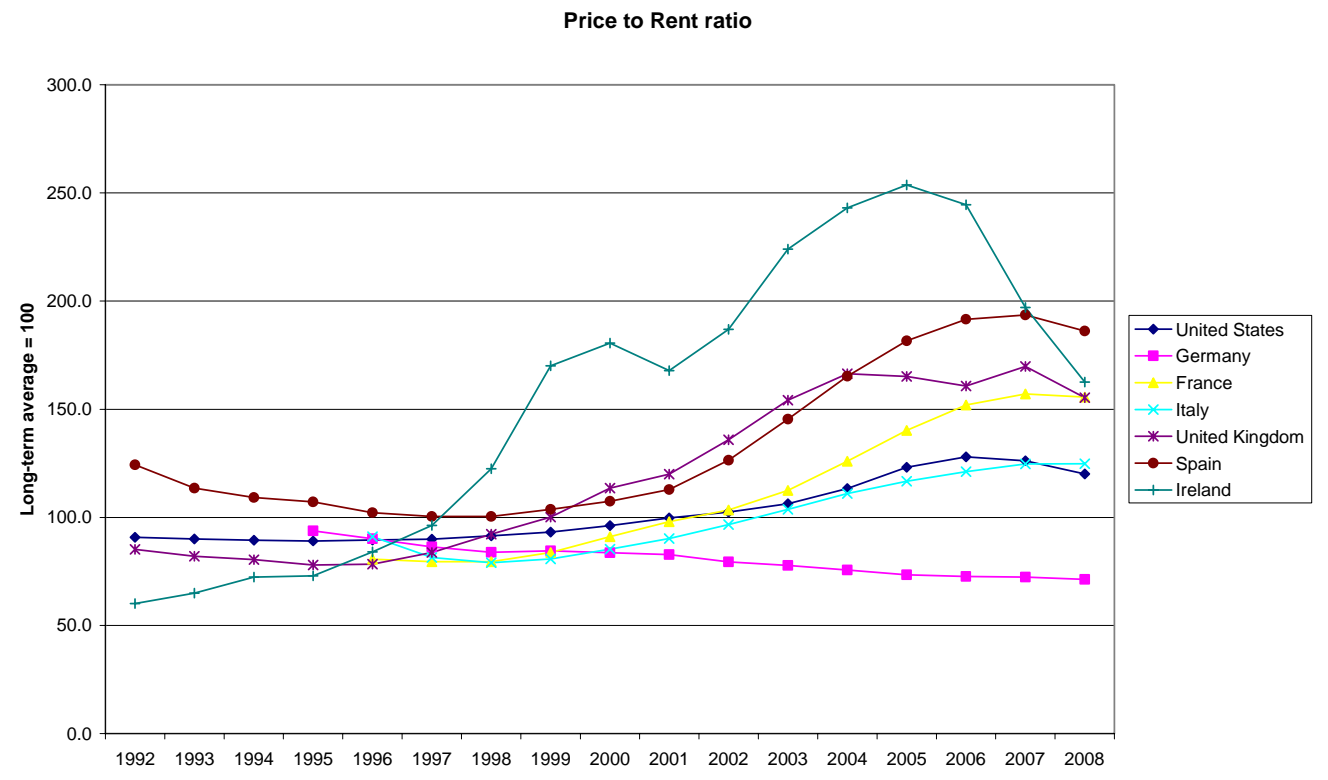

Source: OECD Economic Outlook.

Given these observations, the question arises how taxes might influence house prices. To answer this question, it is helpful to break down the decision of buying a house into its two economic dimensions: $:^{24}$ a consumption decision and an investmentproduction decision. The first facet is related to the decision of households to 'consume' housing services, which is mainly related to the quality of the house. The household decides what type of house and in which location he would like to 'consume'. The investment-production decision is related to the potential value increase of the property, as households also take into account that owning a house is an investment. Housing is a durable good which can potentially be sold at a higher price, even after years of use. This makes the decision of buying a house more complex than consumption decisions for other goods which are mainly based on price and consumer's budget constraint.

Taxes can influence this latter decision via the real user cost of housing capital, defined as the costs of owning and operating the property. Among those costs, one can identify the foregone interest earnings on the equity in the house, the interest cost of funds borrowed to purchase the house, the depreciation of the structure, maintenance, insurances, property taxes and the real estate transaction costs. Since housing is a durable good that can be resold, one has to also account for capital gains or losses that may reduce or increase the final user cost. Taxation affects several of those items and therefore influences the demand for housing. For example, the deductibility of mortgage

\footnotetext{
${ }^{24}$ A detailed analysis of the functioning of the housing market can be found in Pozdena (1988).
} 
interest payments (while earnings on alternative equity investments would have been taxed), the taxation of capital gains or the treatment of imputed rents from owner occupied-housing may all influence the demand for housing. ${ }^{25}$

Even though taxes influence house prices, taxation was probably not the key factor for the recent speculative bubbles, neither in Spain and Ireland nor in the United States. The driving forces behind the boom in the construction sector were rather instead low real interest rates and the rapid expansion of credit. While, for the U.S., low interest rates were a consequence of the Federal Reserve's policy in the aftermath of the tech bubble burst and the economic turmoil following September 11, the reasons for Spain and Ireland could possibly have been - among other factors - the introduction of the Euro, which led to lower interest rates. These low interest rates together with relatively liberal mortgage markets and low transaction costs in housing markets have been cited to be important reasons for the housing price bubble in these two countries. ${ }^{26}$

Taxes may also play a role because the tax regime in many countries provides incentives for households to take on large amounts of debt as interest payments are often tax-deductible. Consequently, taxes can influence the volatility of the housing market. Many countries subsidize mortgage debt in order to stimulate house ownership while levying relatively low property taxes. The favourable tax treatment not only results in a higher steady-state level of house prices but may also interact and magnify shocks that hit the supply or the demand side of the housing market since taxes affect the real user cost of housing (Poterba, 1984). The real user cost of housing model takes the view, that changes in the after-tax user cost are responsible for shifts in housing demand which in turn influence the housing price movements.

Van den Noord (2005) applies Poterba's model to analyse the effect of tax policy on house prices in Europe. In his study on eight European countries ${ }^{27}$ between 1970 and 2001, he finds evidence that price volatility is higher in low-housing-tax countries while volatility is lower in countries where owner-occupied housing is taxed. However, the most recent data from the European Central Bank on the Residential Property Price Index Statistics in 17 EU countries show that real prices of residential property increased

\footnotetext{
${ }^{25}$ For a theoretical analysis of capital gains taxes on housing see Fuest, Huber and Nielsen (2008). While it is often argued that capital gains taxes could reduce price volatility, the authors show that the taxation of capital gains might lead to even bigger price swings.

${ }^{26}$ Ahearne, Delgado and von Weizsäcker (2008) argue that the low real interest rates and the favourable tax treatment of home ownership are important determinants of the housing price bubbles in these countries.

27 Germany, France, Italy Spain, the Netherlands, Belgium, Finland, and Ireland.
} 
significantly in all countries since 2001 (figure 13), bar Austria and Germany where prices decreased. Thus, the role played by taxes in those increases is not easy to determine and further research is needed on the effects of taxes on residential housing.

Figure (13): Development of real house prices between 1997 and 2008

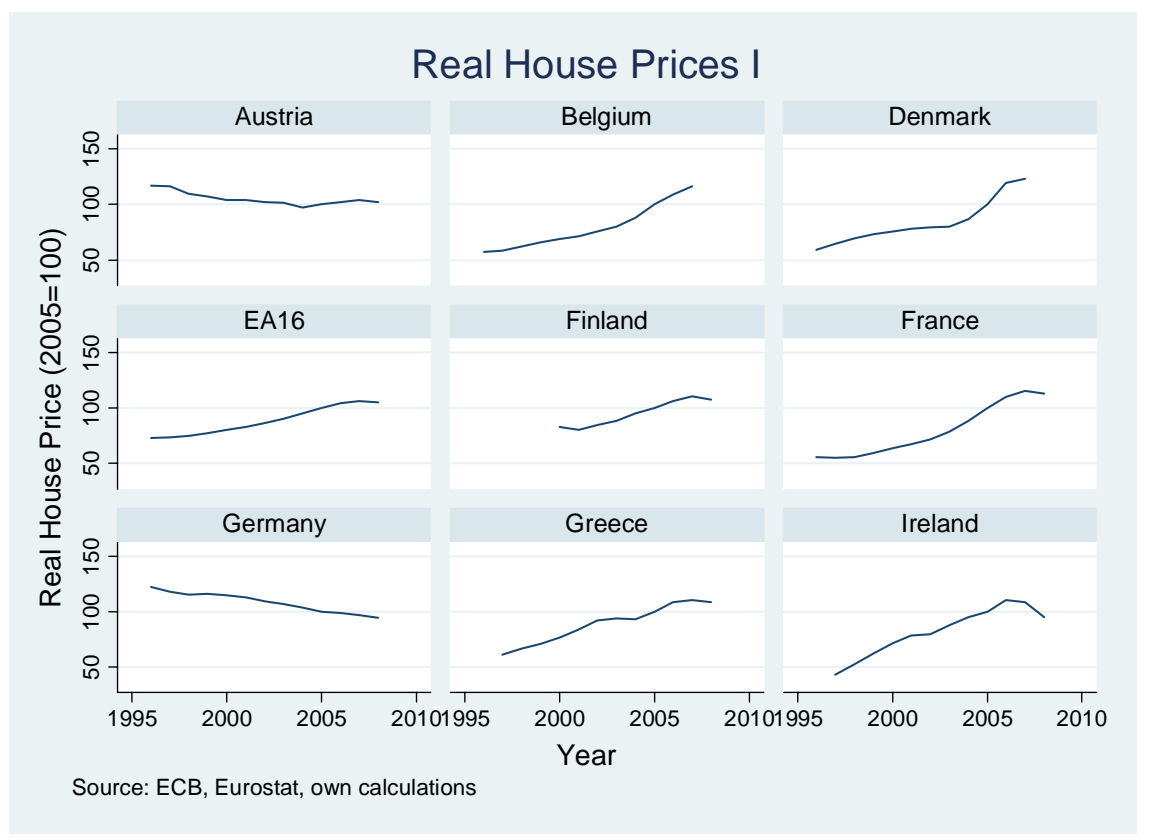

Note: Type of residential property: Residential property prices, new and existing dwellings; Geographical coverage: Whole country.

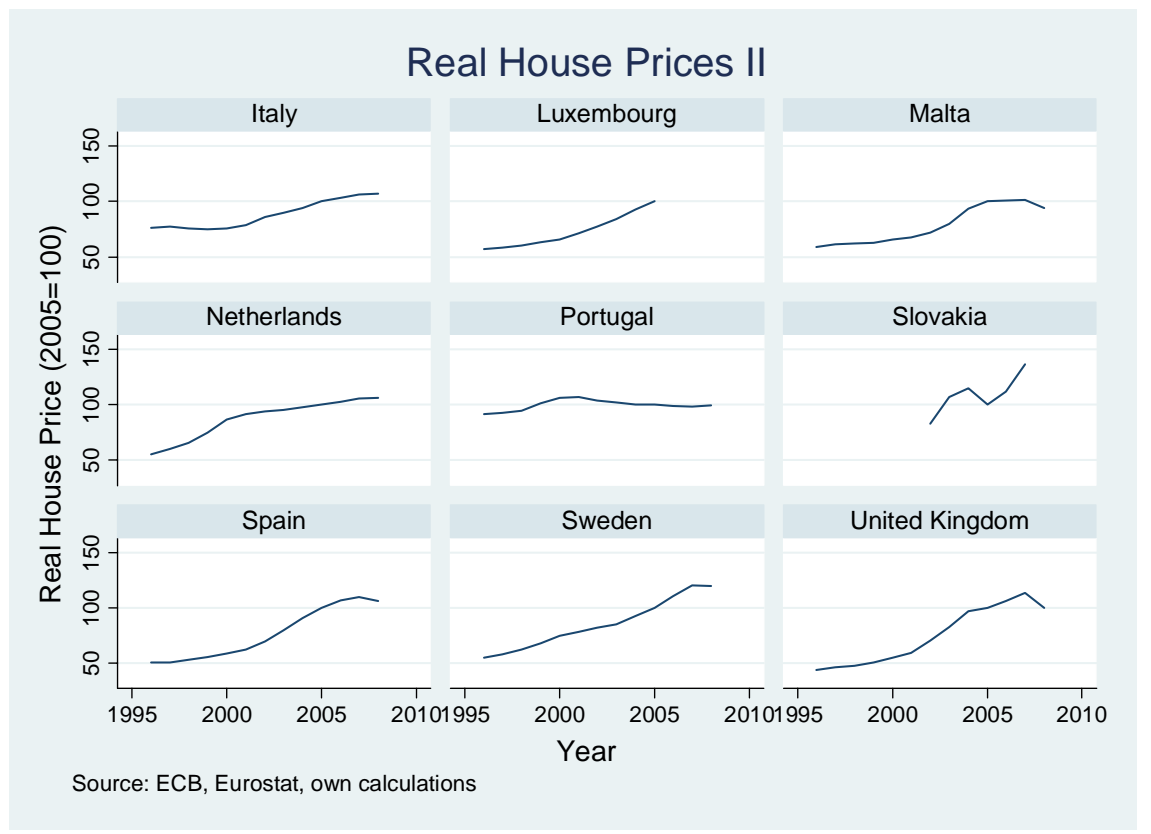

Note: Type of residential property: Residential property prices, new and existing dwellings; Geographical coverage: Whole country.

There may be a tendency in many countries to create tax incentives that lead to over-investment in housing which in turn leads to lower diversification of households' investments, excessive home ownership and excessive leverage by home-owners. A 
reduction of mortgage deductions and the taxation of imputed rents from owner-occupied housing might lead to more stable housing markets since gains and costs from housing would be treated more similarly. This would also increase tax revenues that could finance part of the debt accumulated when setting up recent stimulus packages, provided their level is not negligible. Taxes on immoveable property mainly consist of regular annual levies on land or buildings (residential or commercial) and taxes on property transactions. Their revenue is not very large, representing less than three percent of total revenues from taxation in 19 Member States out of $25 .^{28}$ The main exception is the UK, where taxes on real estate levied on both residential and commercial property make up for over one tenth of total tax revenues. As a share of GDP, revenue varies from a low of $0.21 \%$ in Hungary to close to $4 \%$ of GDP in the UK. Table (3) shows the level of revenue from real estate taxes in all EU Member States, except Luxembourg and the Netherlands.

\footnotetext{
${ }^{28}$ There is no information for Luxembourg and the Netherlands.
} 
Table (3): Revenue from real estate taxes in the EU Member States, 2007

\begin{tabular}{lrr}
\hline Member state & \% of GDP & \% of Total Tax Revenue \\
\hline \hline Austria & 0.43 & 1.04 \\
Belgium & 1.15 & 2.63 \\
Bulgaria & 0.18 & 0.55 \\
Cyprus & 0.71 & 1.73 \\
Czech Republic & 0.42 & 1.15 \\
Germany & 0.72 & 1.83 \\
Denmark & 0.98 & 2.02 \\
Estonia & 0.23 & 0.69 \\
Greece & 0.68 & 2.15 \\
Spain & 0.78 & 2.13 \\
Finland & 0.47 & 1.10 \\
France & 1.81 & 4.21 \\
Hungary & 0.21 & 0.53 \\
Ireland & 0.62 & 2.00 \\
Italy & 1.00 & 2.32 \\
Lithuania & 0.36 & 1.22 \\
Latvia & 0.86 & 2.84 \\
Malta & 1.47 & 4.24 \\
Poland & 1.07 & 3.10 \\
Portugal & 1.18 & 3.25 \\
Romania & 0.90 & 3.09 \\
Sweden & 0.84 & 1.75 \\
Slovenia & 0.55 & 1.46 \\
Slovak Republic & 0.38 & 1.33 \\
United Kingdom & 3.82 & 10.51 \\
\hline \hline
\end{tabular}

Source: 'Taxes in Europe' Database'. Note: For some countries the amount is underestimated due to omission of transaction taxes not exclusively levied on real estate or of minor levies.

The picture given by table (3) is however incomplete because tax revenues can also be raised on property in additional indirect ways (for which we lack reliable data). For instance, property ownership may be taxed under the personal income tax. This is quite straightforward in the case of leased property, as the tax will be calculated on the rent collected. In the case of owner-occupied housing, the assessment of the 'proper' taxable base is more difficult, as it theoretically reflects the rental value that could be collected if the property were put on the market. Many countries have more or less given up attempting to determine the exact current value of property and use revaluated historical values instead, often yielding much lower tax bases. It is hard to assess the order of magnitude of this source of taxation, but it seems unlikely to be very large both because data show the share of PIT revenue from capital income to be low in almost all Member States (European Commission, 2009c) and governments often grant tax relief on mortgage payments, which then offsets the PIT revenue to a significant extent. Another 
example of indirect ways of taxing property is to raise taxes on goods and services that are complementary to housing, such as mortgages or house insurance contracts. In addition, immovable property is typically subject to non-negligible one-off taxation upon inheritance. The levels of revenue raised in this way vary again considerably among Member States. By and large, typical revenue levels vary between a negligible amount and $1 / 2$ percent of GDP, only part of which is realised on immovable property (European Commission, 2009c).

In conclusion, tax incentives may have played a role in the development of the housing bubble but the size of this role is difficult to assess, although the odds are that this role has been secondary to monetary policy and credit markets developments.

\subsection{Executive compensation}

Since the 1990's, we have observed a tendency for companies to develop specific executive compensation schemes, such as stock option plans. In several countries, those schemes benefit from favourable tax treatment such as deductibility at the corporate income tax, exemption from personal income tax or social security contribution ${ }^{29}$. Such favourable tax treatment may have led managers to favour the use of stock options in lieu of traditional wages and to focus on short-term - sometimes window dressing - measures to increase the value of their stocks. This may have increased corporate short-term risktaking and contributed to speculative bubbles.

More recently, several countries have introduced legislative measures to implement additional taxes on bonuses above specific thresholds. For example, UK has introduced an additional $50 \%$ bank payroll tax on the excess bonuses over $£ 25,000$.

\subsection{Securitization and tax arbitrage}

A growing concern relates to the interaction between tax policy and securitization. Tax differentials across types of investors may have created vast opportunities for tax arbitrage, which could be seized by securitization. This is the Tax Arbitrage Feedback Theory (TAFT) developed by Eddins (2009) ${ }^{30}$ for whom "Credit default swaps are revealed to be a massive tax arbitrage that shifted government tax receipts to Wall Street bonus pools and necessitated the creation of massive quantities of low credit quality debt".

${ }^{29}$ See Ceriani (2009) for a discussion. 
The process is the following: investors will buy assets that have a probability $\beta$ of default. In the No Default scenario, the assets will yield a return that will be taxed at the tax rate on interest payments $T_{\text {int }}$. In the Default scenario, investors will receive a recovery $\mathrm{R}$ and will be able to write-off capital losses deductions (1-R) at the long term capital gain tax rate $\mathrm{T}_{\text {losses }}$. The expected after-tax return is therefore a weighted average of the expected returns in the alternative cases with the probabilities of default $\beta$ and no default $1-\beta$ as weights. The investor can in addition insure against the risk of default by buying an insurance (here a Credit Default Swap) to a markt-to-market business trader who will pay the actual credit losses in case of default. These business traders are a special class of taxpayers in the U.S. tax code for which long-term and short-term capital gain are treated as ordinary income under the corporate income tax. By buying insurance, the traditional investor will change his expected cash-flow but will also change his tax liability which now becomes a function of the difference between the return and the premium paid for the insurance, taxed at the tax rate on interest payments $T_{\text {int }}$. By doing this, the investor is able to insure against the risk of default but also to reduce its expected tax liability by an amount that is a function of the probability of default and the difference between the tax rates $\mathrm{T}_{\text {int }}$ and $\mathrm{T}_{\text {losses. }}$

In the TAFT model, the trader is able to extract from the investor a premium for the insurance that is equal to this expected reduction in tax liability. The trader will next reinsure the default risk with a synthetic bond manufacturer (who securitizes the asset e.g. into a Collaterized Debt Obligation) to neutralize the risk. The trader will himself pay a premium to the synthetic bond manufacturer but, because his tax rates on the return on investment and on the recovery of losses are identical, the computed premium will be lower than the one he receives from the traditional investor. The difference between the two premiums represents his profit and TAFT shows that it is exactly equal to the savings on tax liability made by the investor.

This arbitrage is extremely powerful because it is purely based on tax differences and there is hence no market mechanism that can correct it. It also provides huge incentives to develop securitization and insurance financial tools to shift revenues from treasuries to business traders, and this as long as the synthetic bond manufacturer remains solvent. The TAFT is a seducing and rather convincing theory. The future challenge is now to empirically test it.

\footnotetext{
30 See Eddins' (2009) contribution.
} 


\section{Can tax policy help us avoid previous mistakes?}

As we have seen in section (4), taxes have had the potential to exacerbate behaviours that may have contributed to the crisis. The taxation of housing and of executive compensation, as well as the potential tax arbitrage created by differences in taxation of various classes of investors will certainly deserve more attention in future research. In this section, we focus on two issues which have attracted some recent attention: the opportunity to introduce a transaction tax and the possibilities to achieve more tax neutrality between various sources of financing for companies.

\subsection{Financial Transaction Taxes as a way forward?}

Currently, distrust in the functioning of financial markets is increasing in many countries in light of the events of the last two years. The current crisis indeed showed that possibly in part due to lax regulation, financial markets did not work properly in some areas. Recently, the discussion on how to correct potential market imperfection gained momentum and the introduction of a financial transaction tax as a tool to stabilize financial markets and improve their functioning is one of the policy options that are being discussed. In the most recent discussions on proposals for a financial transaction tax, it is argued that such tax could solve three problems at the same time:

1. Stabilize the financial markets by reducing speculative and technical trading, especially in the derivatives market by increasing transaction costs.

2. Raise substantial tax revenue while creating only small distortions in the real economy.

3. Serve as a contribution of the financial sector to the financing of bail-out costs caused by the financial crisis.

The revenue potential of a financial transaction tax depends on assumptions on the rates, the tax elasticities and the administrative design of the tax. Despite the importance and relevance of the topic, such analysis goes beyond the scope of this paper 
which looks at ways for tax policy to prevent future crisis. We therefore concentrate on whether a financial transaction tax could reduce markets' volatility.

The proponents of an intervention argue that the tax could improve financial markets by reducing speculative short-term activities, which they consider as a reason for price volatilities and price bubbles. ${ }^{31}$ The basic idea is that this tax would decrease the volume of speculative activities which are seen as detrimental to the stability and functioning of financial markets and which could lead to overshooting prices. ${ }^{32}$ The mechanism behind this argument is straightforward: The introduction of a tax would increase transaction costs in financial markets and this would in turn reduce the number of transactions. It is argued that especially potentially harmful financial activities like short-term speculation and technical trading with a high amount of transactions per day would be reduced even by a very low tax rate. On the other hand, long-run investments would not be distorted by such a low tax rate due to their low frequency of transactions. Essentially, the debate on financial transaction taxes boils down to the question of the influence that transaction costs have on trade volume, price volatility, and if they can serve as a corrective device to reduce the number of allegedly harmful short-term traders. As will be discussed below, answering these questions is a challenging task.

In general, most current proposals advocate a general and uniform financial transaction tax on the European level that would be imposed on transactions of all kinds of financial assets. ${ }^{33}$ Proponents of the tax usually assume that asset markets are subject to excessive liquidity and excessive price volatility in the medium-run and identify shortterm speculation and technical trading as one major source for this. They argue that a general and uniform ad-valorem transaction tax would decrease speculative short-term trading since the tax would be levied on the notional value of each transaction.

Current proposals consider levying a general and uniform tax on the exchange of all kinds of financial assets. In this case all spot and derivatives transactions on organized exchanges as well as all over-the-counter (OTC) transactions which are directly related

\footnotetext{
${ }^{31}$ Section 2 shows that the current crisis has raised many institutional questions such as the optimal size of financial intermediaries, capital requirements for banks, the design of contracts for traders and managers, general principal-agent problems, and possible regulatory failures in financial markets. As a result, many recent debates concentrate on regulatory reforms, especially for OTC markets. While acknowledging these issues, this section focuses on the role of noise, technical and speculative trading in financial markets. This is justified by the fact that transaction taxes seem to be proposed to specifically affect these traders by increasing transaction costs while their effect on the above-mentioned institutional topics is at best modest.

32 The idea of transaction taxes is not new and some countries have had various experiences with these taxes. An overview is given by Campbell and Froot (1994).

${ }^{33}$ See for example the proposal by Schulmeister, Schratzenstaller and Picek (2008).
} 
to asset prices as well as the related derivatives would be taxed. The statutory tax rates proposed would be low and range from $0.01 \%$ to $0.05 \%$. If a global implementation of the tax fails, most proponents suggest introducing the tax at the EU-level.

The tax base would be the notional value of the asset, defined as the value of a derivative's underlying assets at the spot price. In the case of options or futures contracts, this is the number of units of the asset underlying the contract, multiplied by the spot price of the asset. The notional value is used to take into account the (sometimes substantial) leverage of financial instruments, like derivatives. ${ }^{34}$ The administrative costs of collecting a financial transaction tax could be very low compared to other taxes. Data from the United Kingdom (UK) show that the collection cost for the stamp duty is around 0.11 Pence per Pound collected, to be compared with 1.59 Pence for the income $\operatorname{tax.}^{35}$

The evaluation of the economic impacts of such a tax often depends on the authors' assessment of the functioning of financial markets, especially on their assumptions about investors' behaviour. Two basic strands can be distinguished ${ }^{36}$. One is based on the market efficiency hypothesis ${ }^{37}$, a view on financial markets which was dominant until the end of the eighties. The October 1987 stock market crash and the growing empirical evidence that stock price volatility cannot be explained by changes in dividends helped however the development of a different view on the way financial markets work. This second strand describes the market as a mixture of uninformed traders (so-called "noise traders") who do not take into account economic fundamentals when investing and of a group of rational investors who have rational expectations about the return on securities. ${ }^{38}$

Supporters of the market efficiency hypothesis see transaction taxes as distorting financial markets and leading to higher volatility of prices and less trade volume. They argue that the lower the transaction costs in the market, the better the market performance. The attitude of the noise trader approach towards the transaction tax

\footnotetext{
${ }^{34}$ The use of the notional value could however lead to substantial problems. Since the real cash-flows connected to the purchase of the derivative are much smaller than its notional value, the tax burden differs significantly across derivative products. In cases where margins are very small, the actual tax rate might be much higher than the above mentioned rates. This leads to the problem that the real burden of the tax is very high, changing between products and increasing the cost of hedging activity for companies.

${ }^{35}$ See Bond, Hawkins and Klemm (2004).

${ }^{36}$ This separation is of course very simple and the literature is much wider. For the sake of a short presentation we concentrate however on these extreme views.

${ }^{37}$ A review of this literature is given by Fama (1970).
} 
depends on the assumption about the function of noise traders. If their behaviour is seen as a necessary condition for a proper functioning of the market, scholars would oppose the tax because, in this case, noise traders complement informed investors by taking their open positions and a transaction tax would hamper this useful activity. If noise trading is seen as harmful and if the costs associated with it are hence welfare decreasing, the transaction tax is seen as a useful device to tax detrimental activities of these groups, leading to more efficient financial markets.

Financial transaction taxes have been discussed for long, especially after economic downturns, starting with Keynes' (1936) reflections on stock markets following the Great Depression. He argued that a "substantial government transfer tax on all transactions might prove the most serviceable reform available with a view to mitigating the predominance of speculation over enterprise in the United States." (Chapter 12, VI, p. 143). The rationale for his statement was that firms would concentrate on short-term performance rather than long-run prospects because of speculation. On the other hand, Keynes also pointed out that "If individual purchases of investments were rendered illiquid, this might seriously impede new investment, so long as alternative ways in which to hold his savings are available to the individual. This is the dilemma." (Chapter 12, VI, p. 144). This illustrates admirably the debate which takes place ever since about the role of trade volume and liquidity and its effects on price volatility and on financial markets efficiency.

The idea of a financial transaction tax is also linked to the proposal of James Tobin on an international uniform tax on all spot currency conversions. Tobin (1974, 1978) argued that the increased mobility of private financial capital - especially after the end of the Bretton Woods system - might lead to excessive shifts of funds that create real economic costs for national governments and economies. Tobin reasoned that the tax would increase the effectiveness of domestic monetary policy. Eichengreen, Tobin, and Wyplosz (1995) argue that a transaction tax on currency exchange could create some scope for differences in national tax rates. This in turn would allow national monetary policy to better react to domestic macro-economic needs. ${ }^{39}$ With the introduction of the Euro, the discussion on speculation in currency markets became less important for Europe since the single currency made such speculations impossible within the euro-

\footnotetext{
${ }^{38}$ See Summers and Summers (1989) for a discussion. Note that noise traders and technical traders are related, as explained later.

${ }^{39}$ Garber and Tailor (1995) present a sceptical note on this argument.
} 
area. Currency crises in the 1990's in Russia and Asia led nevertheless to renewed discussions on the potential benefits of such a currency transaction tax. In this context, it was primarily seen as a penalty on short-term currency speculations. At the time, such tax became increasingly popular among non-governmental organisations that saw it as a device for raising revenue to finance development aids or similar projects while at the same time reducing the size and improving the performance of financial markets. The idea of such a "double dividend" can still be found in current discussions.

While Keynes (1936) focused on stock markets and Tobin $(1974,1978)$ focused on currency transactions, the idea of a general and uniform financial transaction tax as proposed by Schulmeister, Schratzenstaller and Picek (2008) is to levy a tax on all kinds of financial transactions. The idea of a more general securities transaction tax has also been put forward by Stiglitz (1989) and Summers and Summers (1989). After the October 1987 stock market crash, they argued that noise traders drive stock prices away from fundamentals, which might lead to higher volatility and price bubbles. Similar to the proponents of the currency transaction tax, they argued that higher transaction costs would reduce the amount of speculative trading and in turn give more room to trading based on fundamental economic data. Stiglitz (1989) argues that the private return of gathering information in order to respond quicker to market changes is higher than the social return of this activity. Levying a tax on these activities would improve economic efficiency of the market by reducing the incentives for this sort of rent-seeking. When discussing the potential side effects of such a tax, he assumes that price volatility in the financial market is not increased but instead decreased. This is a critical assumption. As shown below, the question of how volatility is influenced by such a tax is central to its evaluation.

Other studies find that short-term investment and speculation might be efficiencyimproving. For instance Dooley (1996) argues that the assumption that the tax falls differentially on different types of investors is invalid and it is not clear that investors who base their decisions on fundamentals have longer holding periods than pure speculators. Mixed results can however be found in Subrahmanyam (1998) who finds that transaction taxes do indeed reduce market liquidity but also reduce rent-seeking behaviour for obtaining private information - an element also pointed out by Stiglitz (1989). Schwert and Seguin (1993) surveyed the arguments for and against transaction taxes. They conclude that there is little evidence that the potential beneficial effects of a transaction tax outweigh the potential costs due to tax avoidance and unclear 
tax incidence. In conclusion, the theoretical discussions give a mixed picture of the potential effects of financial transaction taxes.

One of the main arguments for a financial transaction tax is that it would increase transaction costs and therefore reduce trade in highly speculative trading as well as in noise trading and related technical trading. Technical trading is typically based on the analyses of recent price information and volumes traded, and the analysis of fundamental economic data is ignored. When prices have recently risen, technical traders buy until a certain ceiling is reached. If there is a decrease in prices, traders sell when prices fall below a certain minimum (similar to stop-loss-orders). Shleifer and Summers (1990) relate technical trading to noise trading by assuming that technical traders base their models on noise rather than on information. A model of noise trading was developed by De Long et al. (1991). Nevertheless, there is still no explanation on the identity of noise traders are or on their motives (Dow and Gorton, 2006).

Proponents of the financial transaction tax argue that this tax would reduce noise and that technical trade would in turn increase the share of trade based on economic fundamentals and make financial markets more stable and less volatile. The underlying assumption is that most of short-term trading is indeed either highly speculative or based on technical trading which only relies on historical asset prices but does not take into account fundamental economic data. This is a critical assumption since short-term financial transactions are in reality also related to financing and securing investments and trade (e.g. hedging). Furthermore, the tax does not differentiate between speculative and non-speculative transactions. All short- and long-term transactions are taxed, including the reallocations of savings and investment policies of pension and insurance funds. As pointed out above, it is also unclear what are the motivations and intentions of noise traders. This makes it difficult to argue that a tax would actually alter their behaviour.

Theoretical studies have not led to conclusive results mainly because results usually depend on the authors' assumption about the functioning of the market. ${ }^{40}$ It is therefore interesting to check whether empirical evidence gives a clearer picture. At first glance, the various empirical studies leaves the reader with the impression that the empirical relationship between an increase in transaction costs (either via taxes or other means) and market functioning is equally inconclusive. In the last two decades, a number

\footnotetext{
${ }^{40}$ Song and Zhang (2005) rationalize both views in a general equilibrium framework with noise trading. They argue that the result whether a tax increases or decreases volatility is contingent on the market conditions.
} 
of empirical studies have been conducted to measure the effect of changes in transaction costs and many of them lead to opposite results. However, a closer look at these studies shows that the quality of the data and the estimation techniques substantially differ. Many papers based on time series face problems in identifying increases in transaction costs and in disentangling those from other potential effects on trade volume and volatility (Umlauf, 1993; Saporta and Kan, 1997).

More recent papers have improved this by using panel data and estimations technique that allow separating market-wide volatility from volatility caused by transaction cost changes. Hau (2006) shows that transaction costs increase volatility using panel data from the Paris Stock Exchange. The effect of stamp duties on prices was analysed for the UK by Bond, Hawkins and Klemm (2004). The paper uses a natural experiment approach which allows them to use fixed-effects in their estimations in order to capture otherwise unobservable effects and identify the change of transaction costs. ${ }^{41}$ A similar approach with difference-in-differences estimation was taken by Jones and Seguin (1997) for data on the reduction of commission fees at the New York stock exchange. Since this reduction was not the same for all markets, they could set up a treatment and a control group to estimate the effects. There results reject the hypothesis that a decrease of transaction costs increases volatility. ${ }^{42}$

Two other recent papers using time series show that results can indeed be conflicting. Baltagi, Li and Li (2006) use data from stock exchanges in China and show that stamp tax rate increases from $0.3 \%$ to $0.5 \%$ leads to a trading volume decrease by a third. This translates into an elasticity of turnover with respect to a stamp tax of -0.5. They also find that volatility increases significantly. On the other hand, Liu and Zhu (2009) find that the relationship between transaction costs and price volatility is negative in Japan, a result in line with Stiglitz (1989) and Summers and Summers (1989) argumentations. The authors cannot use the estimation approach of Jones and

\footnotetext{
${ }^{41}$ Natural Experiments have first been used in labour economics in the 1970s. The concept was later applied to tax reforms in order to isolate tax effects from other influences on economic decisions. The idea of this approach is that reforms often generate two groups of individuals: A "control group" which is not affected by the tax change and a "treatment group" which faces different taxation after a reform. By comparing the behavioural differences of the two groups after a reform one can measure the influence of the tax change.

${ }^{42}$ Note that proponents of the tax usually argue that studies that concentrate on short-term volatility are irrelevant since the medium-term volatility is the relevant variable that is driven by technical traders. The problem however is that it is not clear whether or not the influence of technical trading on this mediumterm volatility is also driven by the business cycle and other factors that drive prices. Therefore concentrating on short-term volatility is probably the best proxy available for econometric analysis. There
} 
Seguin (1997) since the reduction of transaction was for the whole Japanese market. They therefore have to create what they call "second-best control portfolios" in order to identify the cost effect. More recent research based on experimental economics as well as some theoretical work points to the fact that the effects of such a tax depend on the market structure. ${ }^{43}$ For the European discussion and further research on this topic it is necessary to evaluate the market structure in the different financial centres in Europe. If this structure is heterogeneous, the tax might affect the markets in question very differently. The empirical literature comes thus to different results when evaluating the effects of transaction taxes. While most studies find that trade volume is reduced, the effects on volatility and prices is less clear even though results based on panel data and estimation approaches that better identify transaction cost effects seem to find more often a positive relationship between transactions costs and volatility. For the discussion of the financial transaction tax in Europe one should keep in mind that would be important to analyse the structure and functioning of the single national financial markets. The effects of the tax might be varying depending on the products traded and the way dealers and brokers interact in the market.

To summarize, the evaluation of a financial transaction tax depends largely on the underlying assumptions about the functioning of the financial market and whether the potential market failure can be corrected using a transaction tax. In general, the proponents of the tax argue that the tax would reduce the number of noise traders and consequently of technical trading. Furthermore, the tax would decrease price volatility and unproductive short-term speculation since investors would concentrate on the longrun return of projects. Last but not least, the proponents argue that the tax would lead to substantial tax revenue. The opponents of the tax argue that it would increase transaction costs. This increase in transaction costs would reduce liquidity of markets and therefore market efficiency. It would decrease stock prices and increase the cost of capital companies leading to less investment. They also argue that such a tax would shift transactions away to other markets in countries which do not apply a financial transaction tax. Furthermore, the incidence of the tax is unclear. It might be that the tax falls on bank clients or on companies via higher costs of financing and hedging risk.

is also no theoretical model which could explain why short-term trading is indeed increasing medium-term volatility.

${ }^{43}$ See Hanke et al. (2007) and Pelizzari and Westerhoff (2007). 
Are there alternative ways to mitigate the problems identified by the proponents of a financial transaction tax, e.g. the risk of high volatility, price bubbles, and potentially speculative and highly risky activities in the financial sector? From an economic point of view, a sound and uniform European regulation of the financial sector seems to be an alternative to improve the long-run stability of financial markets. In particular, the regulation of OTC markets is of high importance in order to gain a better overview of counterparty risk in financial markets. The European Commission proposed already a better co-ordination of national supervisors, harmonisation of national regulatory rules and the creation of a common European rule book. ${ }^{44}$ Next to improving institutional regulations, an increase in the capital requirements of financial intermediaries might be an option to increase the liability of banks when they engage in risky investments. This would increase costs for the financial sector and it might reduce the risk of taxpayers. The regulatory option also avoids the uncertainties on market volatility that exist with a financial transaction tax. Nevertheless, despite these uncertainties, the financial transaction remains an issue for future policy debates given its potential revenue-raising capacities.

\subsection{Corporate taxation and financing neutrality}

Current corporate tax systems in Europe favour debt financing over equity financing. While, in general, interest payments on corporate debt are deductible from the corporate tax base, return on equity is not. This leads to a higher leverage for firms since financing investments through debt is tax-favoured. This tax distortion has gained more attention recently as the crisis has highlighted the fact that many companies have too high leverage ratios. This could lead to liquidity constraints, especially in times when banks tend to restrict their credit supply. ${ }^{45} \mathrm{~A}$ well-designed tax base that reduces the distortion of the leverage could make companies less vulnerable to a short-term reduction in credits available on the capital market. There is indeed empirical evidence that the leverage of companies is indeed influenced by taxes. Several studies analyse this issue and find that debt policy is consistent with tax considerations (e.g. Desai, Foley and Hines, 2004, Huizinga, Laeven and Nicodeme, 2008). Huizinga et al (2008) find for instance that for stand-alone companies, an increase in the effective tax rate by one

\footnotetext{
44 The European Commission (2009) has already made proposals on better regulation. See: http://ec.europa.eu/internal market/finances/committees/index en.htm.

${ }^{45}$ The IMF (2009c) draws similar conclusions in a recent document on tax policy and the crisis.
} 
percentage-point increases the ratio of debt to assets by .18\%. The impact is larger for Multinationals as it reaches $.24 \%$ for two equal-size companies (with one foreign subsidiary) within the same group.

In principle, two opposing measures exist that might eliminate this distortion by treating both sources of finance in the same way: An Allowance for Corporate Equity (ACE) or a Comprehensive Business Income Tax (CBIT). The ACE would grant a similar deduction for return on equity than for interest paid. This would abolish the tax advantage of debt. At the same time, ACE reduces the tax burden on marginal investment. However, ACE would also lead to a narrower tax base. In order to collect the same amount of tax revenue either the statutory corporate tax rate or other taxes have to be increased to finance such a reform. The CBIT, on the contrary, broadens the tax base by disallowing a deduction for interest payments on debt. If the tax rate remains unchanged, this leads to an increase in tax revenue. The additional revenue can be either used for a reduction in the statutory corporate tax rate or of other taxes if the reform is supposed to be revenue neutral. The tax neutrality of the financing decision is the same as in the ACE case since equity and debt financing are equally treated.

ACE and CBIT have been discussed extensively in the economic literature ${ }^{46}$. Both systems are appealing due to their efficiency properties with regard to the financing decision of companies; however, there is no clear recommendation on which system is most favourable and there are key trade-offs when designing a reform towards any of these pure systems. While in the context of open economies ACE is more prone to profit shifting (in particular when its narrow tax base is accompanied by higher corporate tax rates), CBIT might lead to increased distortions of the marginal investment.

In order to mitigate these effects one might also consider a combination of the two systems. On the one hand, this would lead to financing neutrality. On the other hand, it would reduce possible negative effects of the pure systems. Devereux and de Mooij (2009) look at the design of corporate tax bases with respect to financing neutrality using ACE and CBIT systems as well as a combination of the two. The investigation of the tax distortions of investment financing and the possible measures against these distortions have been analysed in a simulation model. The authors present simulations of different reform options, also comparing the implementation of ACE and CBIT as pure systems with a combination of both. These different types of reforms are investigated both in case

\footnotetext{
${ }^{46}$ See Devereux and de Mooij (2009) for a detailed overview of this literature.
} 
of individual implementation by each European country - with the others sticking to their current tax systems - and in the case of simultaneous implementation by all 27 Member States. Under the assumptions of the model, it is shown that combining the two $\mathrm{ACE} / \mathrm{CBIT}$ systems leads to the same neutrality in investment financing as each single reform but also improves welfare, both in the case of unilateral reforms and of Europewide reforms. Despite the advantages of financing neutrality, ACE or CBIT reforms can be found only in very few Member States ${ }^{47}$. The discussion on the design of corporate tax bases might therefore be topic of interest for policy makers in the European Union in the aftermath of the current crisis.

\section{Conclusions.}

The 2008 financial crisis has already proven to be the worst economic crisis since WWII. The burst of a housing bubble in the United States has led to a stop in confidence of investor towards all mortgage-based assets that had flourished in previous years and to uncertainties with regards to the financial exposure and liquidity of world major financial institutions. This banking crisis eventually spread to a stock market crash and to a credit crunch in the real economy. The rapid expansion of credit and the increasing degree of indebtedness and risk-taking behaviour of financial institutions has been a striking characteristic of the build-up to the crisis.

In this context, one important policy question is whether tax systems may have created negative incentives, favouring risk. Several tax provisions in favour of homeownership may have led to increased purchases of houses in several countries. However, the available evidence is mixed when it comes to assess whether different tax treatments have led to different price developments, suggesting that lax monetary policy and increased risk-taking by lenders are more powerful explanations for the housing bubble. In turn, there is however some hints that this risk-taking behaviour may have been exacerbated by tax provisions on the treatment of executive compensation and by tax arbitrage possibilities across different types of investors, albeit both relationships still need to be empirically validated.

Countries have implemented strong policy responses to the crisis. In particular, many countries have taken tax measures as part of broader fiscal stimulus packages. They have however come short of changing tax systems. Two issues have attracted some

${ }^{47}$ Belgium implemented an ACE system; Germany limited interested deductibility which is a move 
attention. The idea of a transaction tax to prevent speculative bubbles is not recent. For its proponents, such tax would reduce volatility and bring additional tax revenues. A review of the existing theoretical and empirical literature shows however mixed results and does not exclude that such a tax would instead increase volatility. A promising avenue is the development of tax systems that are more neutral with regards to the source of financing as existing systems render debt more tax-attractive, possibly leading to toohigh levels of leverage.

towards CBIT. Italy had ACE elements in its tax system but removed them after a short period. 


\section{References.}

Baily, M.N., Litan, R.E. and M.S. Johnson (2008). The Origins of the Financial Crisis, Fixing Finance Series Paper, 3, Brookings Institutions.

Baltagi, B. H., D. Li and Q. Li (2006) Transaction tax and stock market behavior: evidence from an emerging market. Empirical Economics, 31: 393-408.

Bond, S., Hawkins, M. and A. Klemm (2004). Stamp Duty on Shares and its Effect on Share Prices. The Institute for Fiscal Studies, IFS Working Paper WP04/11.

Campbell, J.Y. and K. A. Froot (1994) International Experiences with Securities Transaction Taxes. In The Internationalization of Equity Markets, pages 277-308. Eds. Jeffrey A. Frankel, National Bureau of Economic Research. University of Chicago Press.

Cecchetti, S. (2007). Federal Reserve policy actions in August 2007: FAQ. VoxEU. http://www.voxeu.org/index.php?q=node/466

Ceriani, V. (2009). The Tax System and the Financial Crisis, presentation at the conference on 'tax policy and the financial crisis', Milan.

Demyanyk, Y. and O. Van Hemert (2009). Understanding the Subprime Mortgage Crisis, forthcoming in Review of Financial Studies.

Desai, M.A., Foley, C.F. and Hines, J.R. (2004). A Multinational Perspective on Capital Structure Choice and Internal Capital Markets, Journal of Finance, 59:2451-2487.

Devereux, M.P. and R.A. de Mooij (2009). Alternative Systems of Business Tax in Europe: An applied analysis of ACE and CBIT Reforms. Taxation Papers, European Commission, 17.

Dooley (1996). The Tobin Tax: Good Theory, Weak Evidence, Questionable Policy, in The Tobin Tax: Coping with Financial Volatility, M. ul Haq, I. Kaul and I. Grunberg (eds), Oxford University Press, 1996, pp. 83-108.

Dow, J. and G. Gorton (2006). Noise Traders. NBER Working Paper Series. Working Paper, 12256. http://www.nber.org/papers/w12256.

Eddins, S. (2009). Tax Arbitrage Feedback Theory http://papers.ssrn.com/sol3/papers.cfm?abstract id=1356159

Eichengreen, B., Tobin, J. and C. Wyplosz (1995). Two cases for Sand in the Wheels of International Finance. The Economic Journal, 105(428). pp. 162-172.

Ernst \& Young (2009). Worldwide Fiscal Stimulus - tax policy plays a major role.

European Commission (2009a), Public Finance in EMU 2009.

European Commission (2009b), The EU's Response to support the real economy during the economic crisis: an overview of Member States recovery measures. European Economy. Occasional Paper, 51.

European Commission (2009c), Taxation Trends in the European Union: 2009 edition

European Commission (2009d), European Economic Forecasts, Autumn 2009.

Fabozzi, F.J. (2005), The Handbook of Fixed Income Securities, $7^{\text {th }}$ Edition, McGrawHill.

Fama, E. (1970). Efficient Capital Markets: A Review of Theory and Empirical Work. Journal of Finance, 25 (2), pp. 383-417. 
Fuest, C., Huber, B. and S.B. Nielsen (2008). Capital gains taxes on housing. Mimeo.

Garber, P. and M. P. Taylor (1995). Sand in the Wheels of Foreign Exchange Markets: A Sceptical Note. The Economic Journal, 105(428), pp. 173-180.

Hanke, M., Huber, J., Kirchler, M. and M. Sutter (2007). The economic consequences of a Tobin tax - An experimental analysis. Working Papers in Economic and Statistics. University of Innsbruck. 2007-18.

Hau, H. (2006). The Role of Transaction Costs for Financial Volatility: Evidence from the Paris Bourse. Journal of the European Economic Association, 4(4), pp. 862-890.

Huizinga, H., Laeven, L. and Nicodeme, G. (2008). Capital Structure and International Debt Shifting, Journal of Financial Economics, 88, pp. 80-118.

International Monetary Fund (2009a). World Economic Outlook 2009 and update at http://www.imf.org/external/pubs/ft/weo/2009/update/02/index.htm

International Monetary Fund (2009b). Global Financial Stability Report Responding to the Financial Crisis and Measuring Systemic Risks, April 2009.

International Monetary Fund (2009c). Debt Bias and Other Distortions: Crisis-Related Issues in Tax Policy. http://www.imf.org/external/np/pp/eng/2009/061209.pdf

Joint Center for Housing Studies of Harvard University (2008), The State of the Nation's Housing 2008, Cambridge MA.

Joint Center for Housing Studies of Harvard University (2009), The State of the Nation's Housing 2009, Cambridge MA.

Jones, C. M. and P. J. Seguin (1997) Transaction Costs and Price Volatility: Evidence from Commission Deregulation. The American Economic Review, 87(4), pp. 728-737.

Keynes, J. M. (1936). General Theory of Employment, Interest and Money. Atlantic Publishers \& Distributors, 2006.

Leaven, L. and F. Valencia (2008). Systemic Banking Crises: A New Database. IMF Working Paper, 2008/224.

Liu, Shinhua and Zhen Zhu (2009). Transaction Costs and Price Volatility: New Evidence from the Tokyo Stock Exchange. In: Journal of Financial Services Research. 36: $65-83$.

Lloyd, G. (2009). Moving beyond the crisis - strengthening understanding of how tax policies affect the soundness of financial markets, Mimeo.

Miller, Merton H. (1991). Financial Innovations and Market Volatility. Basil Blackwell.

O'Kane, D. (2005), Introduction to Credit Derivatives, in The Handbook of Fixed Income Securities, Fabozzi editor, $7^{\text {th }}$ Edition, McGraw-Hill.

Pelizzari, P. and F. Westerhoff (2007). Some Effects of Transaction Taxes under different Microstructures. Quantitative Finance Research Centre Research Paper, 212.

Poterba, J. (1984). Tax Subsidies to Owner-Occupied Housing: An Asset-Market Approach. The Quarterly Journal of Economics, 99(4), pp. 729-752.

Portes, Richard (2009). Global Imbalances. In: Macroeconomic Stability and Financial Regulation: Key Issues for the G20. Mathias Dewatripont, Xavier Freixas and Richard Portes (eds). CEPR. VOX eBook: http://www.voxeu.org/reports/G20_ebook.pdf 
Pozdena, R. J. (1988) The Modern Economics of Housing. Quorum Books. New York. Westport, Connecticut. London.

Schulmeister, S., Schratzenstaller, M. and O. Picek (2008). A General Fi-nancial Transaction Tax. Motives, Revenues, Feasibility and Effects. Research Study by the Austrian Institute of Economic Research. Available online: http://www.wifo.ac.at/wwa/servlet/wwa.upload.DownloadServlet/bdoc/S_2008 FINAN CIAL TRANSACTION TAX 31819\$.PDF.

Schwert, G. W. and P. J. Seguin (1993). Security Transaction Taxes: An Overview of Costs and Benefits and Unresolved Questions. Financial Analysts Journal, 49(5), pp. $27-$ 35 .

Stiglitz, J. (1989). Using Tax Policy to Curb Speculative Short-term Trading. Journal of Financial Service Research, 3(2-3), pp. 101-115.

Subrahmanyam, A. (1998) Transaction Taxes and Financial Market Equilibrium. Journal of Business, 71(1). pp. 81-117.

Summers, L. H. and V. P. Summers (1989). When Financial Markets work too well: A Cautious Case for a Securities Transaction Tax. Journal of Financial Services Research, 3, pp. 261-286.

Tobin, J. (1978) A Proposal for International Monetary Reform. Eastern Economic Journal, 4(3-4), July/ October. Pp. 153-159.

Tobin, J. (1974). The New Economics One Decade Older.

Umlauf, S. R. (1993) Transaction taxes and the behaviour of the Swedish stock market. Journal of Financial Economics, 33, pp. 227-240.

Van den Noord, P. (2005). Tax Incentives and House Price Volatility in the Euro Area: Theory and Evidence. Économie Internationale, 101, pp. 28-45.

Wibaut, S. (2008). Quelles Leçons Tirer de la Crise Financière? Regards Economiques, 64, December. 


\section{CESifo Working Paper Series}

for full list see www.cesifo-group.org/wp

(address: Poschingerstr. 5, 81679 Munich, Germany, office@cesifo.de)

2873 Burkhard Heer and Alfred Maußner, Computation of Business-Cycle Models with the Generalized Schur Method, December 2009

2874 Carlo Carraro, Enrica De Cian and Massimo Tavoni, Human Capital Formation and Global Warming Mitigation: Evidence from an Integrated Assessment Model, December 2009

2875 André Grimaud, Gilles Lafforgue and Bertrand Magné, Climate Change Mitigation Options and Directed Technical Change: A Decentralized Equilibrium Analysis, December 2009

2876 Angel de la Fuente, A Mixed Splicing Procedure for Economic Time Series, December 2009

2877 Martin Schlotter, Guido Schwerdt and Ludger Woessmann, Econometric Methods for Causal Evaluation of Education Policies and Practices: A Non-Technical Guide, December 2009

2878 Mathias Dolls, Clemens Fuest and Andreas Peichl, Automatic Stabilizers and Economic Crisis: US vs. Europe, December 2009

2879 Tom Karkinsky and Nadine Riedel, Corporate Taxation and the Choice of Patent Location within Multinational Firms, December 2009

2880 Kai A. Konrad, Florian Morath and Wieland Müller, Taxation and Market Power, December 2009

2881 Marko Koethenbuerger and Michael Stimmelmayr, Corporate Taxation and Corporate Governance, December 2009

2882 Gebhard Kirchgässner, The Lost Popularity Function: Are Unemployment and Inflation no longer Relevant for the Behaviour of Germany Voters?, December 2009

2883 Marianna Belloc and Ugo Pagano, Politics-Business Interaction Paths, December 2009

2884 Wolfgang Buchholz, Richard Cornes and Dirk Rübbelke, Existence and Warr Neutrality for Matching Equilibria in a Public Good Economy: An Aggregative Game Approach, December 2009

2885 Charles A.E. Goodhart, Carolina Osorio and Dimitrios P. Tsomocos, Analysis of Monetary Policy and Financial Stability: A New Paradigm, December 2009

2886 Thomas Aronsson and Erkki Koskela, Outsourcing, Public Input Provision and Policy Cooperation, December 2009 
2887 Andreas Ortmann, "The Way in which an Experiment is Conducted is Unbelievably Important": On the Experimentation Practices of Economists and Psychologists, December 2009

2888 Andreas Irmen, Population Aging and the Direction of Technical Change, December 2009

2889 Wolf-Heimo Grieben and Fuat Şener, Labor Unions, Globalization, and Mercantilism, December 2009

2890 Conny Wunsch, Optimal Use of Labor Market Policies: The Role of Job Search Assistance, December 2009

2891 Claudia Buch, Cathérine Tahmee Koch and Michael Kötter, Margins of International Banking: Is there a Productivity Pecking Order in Banking, too?, December 2009

2892 Shafik Hebous and Alfons J. Weichenrieder, Debt Financing and Sharp Currency Depreciations: Wholly vs. Partially Owned Multinational Affiliates, December 2009

2893 Johannes Binswanger and Daniel Schunk, What is an Adequate Standard of Living during Retirement?, December 2009

2894 Armin Falk and James J. Heckman, Lab Experiments are a Major Source of Knowledge in the Social Sciences, December 2009

2895 Hartmut Egger and Daniel Etzel, The Impact of Trade on Employment, Welfare, and Income Distribution in Unionized General Oligopolistic Equilibrium, December 2009

2896 Julian Rauchdobler, Rupert Sausgruber and Jean-Robert Tyran, Voting on Thresholds for Public Goods: Experimental Evidence, December 2009

2897 Michael McBride and Stergios Skaperdas, Conflict, Settlement, and the Shadow of the Future, December 2009

2898 Ben J. Heijdra and Laurie S. M. Reijnders, Economic Growth and Longevity Risk with Adverse Selection, December 2009

2899 Johannes Becker, Taxation of Foreign Profits with Heterogeneous Multinational Firms, December 2009

2900 Douglas Gale and Piero Gottardi, Illiquidity and Under-Valuation of Firms, December 2009

2901 Donatella Gatti, Christophe Rault and Anne-Gaël Vaubourg, Unemployment and Finance: How do Financial and Labour Market Factors Interact?, December 2009

2902 Arno Riedl, Behavioral and Experimental Economics Can Inform Public Policy: Some Thoughts, December 2009 
2903 Wilhelm K. Kohler and Marcel Smolka, Global Sourcing Decisions and Firm Productivity: Evidence from Spain, December 2009

2904 Marcel Gérard and Fernando M. M. Ruiz, Corporate Taxation and the Impact of Governance, Political and Economic Factors, December 2009

2905 Mikael Priks, The Effect of Surveillance Cameras on Crime: Evidence from the Stockholm Subway, December 2009

2906 Xavier Vives, Asset Auctions, Information, and Liquidity, January 2010

2907 Edwin van der Werf, Unilateral Climate Policy, Asymmetric Backstop Adoption, and Carbon Leakage in a Two-Region Hotelling Model, January 2010

2908 Margarita Katsimi and Vassilis Sarantides, Do Elections Affect the Composition of Fiscal Policy?, January 2010

2909 Rolf Golombek, Mads Greaker and Michael Hoel, Climate Policy without Commitment, January 2010

2910 Sascha O. Becker and Ludger Woessmann, The Effect of Protestantism on Education before the Industrialization: Evidence from 1816 Prussia, January 2010

2911 Michael Berlemann, Marco Oestmann and Marcel Thum, Demographic Change and Bank Profitability. Empirical Evidence from German Savings Banks, January 2010

2912 Øystein Foros, Hans Jarle Kind and Greg Shaffer, Mergers and Partial Ownership, January 2010

2913 Sean Holly, M. Hashem Pesaran and Takashi Yamagata, Spatial and Temporal Diffusion of House Prices in the UK, January 2010

2914 Christian Keuschnigg and Evelyn Ribi, Profit Taxation and Finance Constraints, January 2010

2915 Hendrik Vrijburg and Ruud A. de Mooij, Enhanced Cooperation in an Asymmetric Model of Tax Competition, January 2010

2916 Volker Meier and Martin Werding, Ageing and the Welfare State: Securing Sustainability, January 2010

2917 Thushyanthan Baskaran and Zohal Hessami, Globalization, Redistribution, and the Composition of Public Education Expenditures, January 2010

2918 Angel de la Fuente, Testing, not Modelling, the Impact of Cohesion Support: A Theoretical Framework and some Preliminary Results for the Spanish Regions, January 2010

2919 Bruno S. Frey and Paolo Pamini, World Heritage: Where Are We? An Empirical Analysis, January 2010 
2920 Susanne Ek and Bertil Holmlund, Family Job Search, Wage Bargaining, and Optimal Unemployment Insurance, January 2010

2921 Mariagiovanna Baccara, Allan Collard-Wexler, Leonardo Felli and Leeat Yariv, Gender and Racial Biases: Evidence from Child Adoption, January 2010

2922 Kurt R. Brekke, Roberto Cellini, Luigi Siciliani and Odd Rune Straume, Competition and Quality in Regulated Markets with Sluggish Demand, January 2010

2923 Stefan Bauernschuster, Oliver Falck and Niels Große, Can Competition Spoil Reciprocity? - A Laboratory Experiment, January 2010

2924 Jerome L. Stein, A Critique of the Literature on the US Financial Debt Crisis, January 2010

2925 Erkki Koskela and Jan König, Profit Sharing, Wage Formation and Flexible Outsourcing under Labor Market Imperfection, January 2010

2926 Gabriella Legrenzi and Costas Milas, Spend-and-Tax Adjustments and the Sustainability of the Government's Intertemporal Budget Constraint, January 2010

2927 Piero Gottardi, Jean Marc Tallon and Paolo Ghirardato, Flexible Contracts, January 2010

2928 Gebhard Kirchgässner and Jürgen Wolters, The Role of Monetary Aggregates in the Policy Analysis of the Swiss National Bank, January 2010

2929 J. Trent Alexander, Michael Davern and Betsey Stevenson, Inaccurate Age and Sex Data in the Census PUMS Files: Evidence and Implications, January 2010

2930 Stefan Krasa and Mattias K. Polborn, Competition between Specialized Candidates, January 2010

2931 Yin-Wong Cheung and Xingwang Qian, Capital Flight: China's Experience, January 2010

2932 Thomas Hemmelgarn and Gaetan Nicodeme, The 2008 Financial Crisis and Taxation Policy, January 2010 